\title{
WHERE THE CONSUMER IS THE COMMODITY: THE DIFFICULTY WITH THE CURRENT DEFINITION OF COMMERCIAL SPEECH
}

\author{
Erin Bernstein \& Theresa J. Lee*
}

2013 MICH. ST. L. REV. 39

TABLE OF CONTENTS

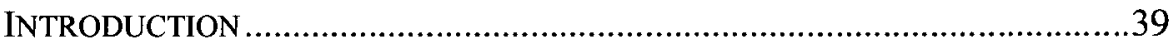

I. COMMERCIAL SPEECH AND THE CONSUMER ........................................45

A. The Development of the Commercial Speech Doctrine ..................45

B. The Definitional Struggle Surrounding Commercial Speech.........55

II. RISE OF NEW ECONOMY BUSINESS MODELS........................................61

A. From Fee-for-Service to Commodifying the Consumer.................62

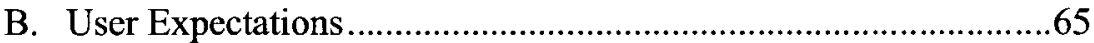

C. Present Regulation by the Federal Government ............................68

III. REDEFINING THE COMMERCIAL IN AN INFORMATION ECONOMY ..........71

A. Audience-Focused Conception of Commercial Speech .................71

B. Commercial Speech, Consumer Expectations, and Shifting

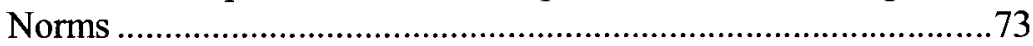

C. Toward a Modern Definition of "Commercial Transaction" .........75

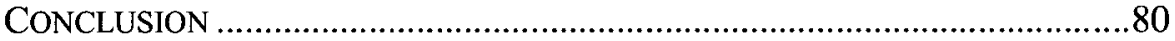

\section{INTRODUCTION}

Imagine a website used by hundreds of millions of people worldwide. The site offers - free of charge- a new, innovative social networking service that people compulsively check several times a day. Now imagine that, in order to entice such a large following, the website hid or misstated the nature of the service offered. For instance, imagine that its advertisements claimed that it would never sell user data to advertisers--but, later realizing the financial potential there, the service began to do so, and reaped large

* Erin Bernstein is a Deputy City Attorney in the San Francisco City Attorney's Office and Lecturer at the University of California at Berkeley Law School; J.D. 2003, Harvard. The opinions in this Article are hers alone and should not be ascribed to the San Francisco City Attorney's Office. Theresa Lee was the 2011-2012 Associate Research Scholar in Law, San Francisco Affirmative Litigation Project Fellow, and Lecturer in Law at Yale Law School; J.D. 2011, Yale. We would especially like to thank Heather Gerken, Tamara Piety, Jack Balkin, Robert Post, and Anjali Dalal for their extraordinarily helpful comments and critiques. Thank you also to Jonathan Meltzer for his excellent research assistance. All mistakes are, of course, our own. 
profits. Now, imagine that the advertisements that drew in the hundreds of millions of users whose data formed the profit backbone of the company were entirely unregulable by government agencies or private lawsuits.

Though this scenario may seem far-fetched, it is a rising possibility. The commercial speech doctrine, tangled though it may be, has been limited in scope to speech that proposes a commercial transaction. But outdated notions of what constitutes a "commercial transaction" threaten to leave the advertisements and other representations to users of services like Facebook, Google, Twitter, Bing, and Pinterest entirely unregulable. While thus far, many of these service providers have been willing to submit to the regulatory authority of the Federal Trade Commission, for example, their use of the First Amendment as a defense in consumer suits has begun to proliferate. ${ }^{1}$ While the actions taken by these companies have not yet implicated the regulatory authority of the government related to advertising, terms of service, or data collection, the dawning recognition of the utility of the First Amendment to these companies underscores the importance of shaping the doctrine to reach modern technologies and business models.

In recent years, the dominant model of fee-for-service or fee-for-goods commercial transactions has shifted. In the past decade, a crop of technological services and social media has used a new model, ${ }^{2}$ or rather, has reinvigorated an old one. ${ }^{3}$ Companies like Facebook, Google, and Twitter offer services used by billions of users that have become central to our dayto-day lives. ${ }^{4}$ These services are free to users. ${ }^{5}$ But, as many shrewd com-

1. Memorandum of Law in Support of Motion for More Definite Statement or Dismissal at 15-18, E.K.D. ex rel. Dawes v. Facebook, Inc., 885 F. Supp. 2 d 894 (S.D. Ill. 2012) (No. 3:11-461-GPM), http://www.scribd.com/doc/76515447/EKD-et-al-v-FacebookMotion-to-Dismiss-Illinois. Google also recently commissioned scholars Eugene Volokh and Donald Falk to write a paper advancing the argument that Google results are fully protected speech. Eugene Volokh \& Donald M. Falk, First Amendment Protection For Search ENGINE SEARCH RESULTS (2012), available at http://www.volokh.com/wpcontent/uploads/2012/05/SearchEngineFirstAmendment.pdf. iTunes).

2. The App Economy, NPR Planet MONEY (Jan. 31, 2012) (downloaded using

3. Current social media and technological services offer their products free to users much like television programming in the days prior to cable television.

4. Key Facts, FACEBOOK NeWSROOM, http://newsroom.fb.com/Key-Facts (last visited Apr. 8, 2013) (reporting one billion Facebook users as of October 2012); Lucy Hodgson, Twitter 2012 [Infographic], BLOG Herald (Feb. 22, 2012, 9:40 AM), http://www.blogherald.com/2012/02/22/twitter-2012-infographic/ (reporting 465 million Twitter users as of 2012); Harrison Weber, Gmail Closes in on Hotmail with 350 MM Active Users, NeXT WeB (Jan. 19, 2012), http://thenextweb.com/google/2012/01/19/gmail-closesin-on-hotmail-with-350-mm-active-users/ (reporting Gmail, Google's web based mail system, has 350 million active users and Google Plus has 90 million users); Dan Farber, Google Search Scratches Its Brain 500 Million Times a Day, CNET (May 13, 2013, 6:16 PM) (reporting that Google processes 100 billion searches per day). 
mentators have noted, when users don't pay for a product, often the user is the product. ${ }^{6}$ That is, companies like Google and Facebook develop a large user base by offering free services and then "sell against" that user base to advertisers, venture capitalists, and other financial backers. ${ }^{7}$

The central focus of this Article is the interplay between traditional commercial speech analysis, which focuses on whether a fee is exchanged for goods or services, and the rise of new non-linear commercial transactions. Current commercial speech doctrine takes a relatively limited view as to what constitutes a commercial transaction. ${ }^{8}$ Though providing an only slightly more expansive understanding on occasion, ${ }^{9}$ the Court has identified commercial speech as that speech that "does 'no more than propose a commercial transaction."'10 This vision of what constitutes commercial

5. See, e.g., FACEBOOK, https://www. facebook.com (last visited Apr. 8, 2013) (stating, "It's free and always will be"); Twitter Terms of Service, TwITTER, https://twitter.com/tos (last visited Apr. 8, 2013) (indicating that upon sign up, the terms of use are meant to be the "entire and exclusive agreement between Twitter" and the user and contain no financial charges to the user).

6. Indeed, Google's FAQ for investors answers the question "[w]ho are our customers?" as follows: "Our customers are over one million of advertisers, from small businesses targeting local customers to many of the world's largest global enterprises, who use Google AdWords to reach millions of users around the world." Investor Relations, GOOGLE, http://investor.google.com/corporate/faq.html\#toc-customers (last visited Apr. 8, 2013); see also Brendan Greeley, The Consumer Privacy Bill of Rights: Are We the Consumers, or Are We the Product?, BloOMBerg BusInESSWEeK (Feb. 23, 2012), http://www.businessweek.com/articles/2012-02-23/the-consumer-privacy-bill-of-rights-arewe-the-consumers-or-are-we-the-product; Freee Bacon!, SEAPEGASUS BLOG (Sept. 27, 2011), http://seapegasus.org/?p=290 (depicting a cartoon of two pigs saying, "Isn't it great? We have to pay nothing for the barn" and "Yeah! And even the food is free" followed by commentary: "Facebook and You: If you're not paying for it, you're not the customer. You're the product being sold."); The "Free" Model, GeEK \& POKE (Dec. 21, 2010, 12:19 AM), http:/geekandpoke.typepad.com/geekandpoke/2010/12/the-free-model.html (showing a cartoon without Facebook-specific commentary).

7. See, e.g., Michael Brush, A Field Guide to the Facebook IPO, MSN MONEY (Feb. 7, 2012, 6:54 PM), http://money.msn.com/investment-advice/a-field-guide-to-thefacebook-ipo-brush.aspx?page $=0$ (noting "Facebook has a wider range of much more targeted personal information to sell against"); Benjamin Pimentel, How Facebook Makes Money Could Change, Wall ST. J. (Feb. 2, 2012, 5:59 PM), http://online.wsj.com/article/BT-CO20120202-720732.html (explaining that $85 \%$ of current revenue stream of Facebook is, like the majority of Google's revenue, supported by selling advertising to be viewed by Facebook's users).

8. See infra Section I.A.

9. Bolger v. Youngs Drug Prods. Corp., 463 U.S. 60, 62, 66-67 (1983) (finding that a pamphlet that merely identified a manufacturer was commercial speech); Cent. Hudson Gas \& Elec. Corp. v. Pub. Serv. Comm'n, 447 U.S. 557, 561-62 (1980) (identifying speech as commercial if it "relate[s] solely to the economic interests of the speaker and its audience").

10. Va. State Bd. of Pharmacy v. Va. Citizens Consumer Council, Inc., 425 U.S. 748, 762 (1976) (quoting Pittsburgh Press Co. v. Pittsburgh Comm'n on Human Relations, 413 U.S. 376, 385 (1973)). In the more recent United States v. United Foods, Inc., the Court 
speech leaves out much of the speech, even economically motivated speech, of corporations and producers."

An inflexible application of a direct profit-focused commercial speech test might place companies like Google and Facebook outside the purview of local, state, or federal laws that seek to regulate their interactions with users. ${ }^{12}$ Current willingness to submit to regulation does not ensure that future attempts at regulation will not be met by First Amendment challenges, especially as these companies appear to only have recently begun thinking about the First Amendment status of their speech and products. ${ }^{13}$ While there may be reasons to be cautious about placing more and more speech within the ambit of commercial speech rather than fully protected speech, ${ }^{14}$ it is equally perilous to afford truly commercial speech the full protections afforded to non-commercial speech under the First Amendment. ${ }^{15}$ The dangers of commercial speech, the interests in ensuring consumers have all

pointed out that over the course of the history of the commercial speech doctrine, commercial speech is "usually defined as speech that does no more than propose a commercial transaction." 533 U.S. 405, 409 (2001). See also Sorrell v. IMS Health Inc., 131 S. Ct. 2653, 2674-75 (201 1). But see Bolger, 463 U.S. at 66-67; Cent. Hudson, 447 U.S. at 561-62.

11. Cf. Kasky v. Nike, Inc., 45 P.3d 243, 247-48, 262 (Cal. 2002) (holding that statements about labor policies, practices, and conditions where athletic shoes and apparel were made were commercial speech). Kasky caused a great deal of uproar in the commercial speech context, and while the Supreme Court initially granted certiorari, it was later dismissed as improvidently granted. Nike, Inc. v. Kasky, 539 U.S. 654, 655 (2003) (per curiam). In a concurrence, Justice Stevens stressed the novelty of the First Amendment questions presented, indicating it was not time for the court to review the status of the "blending of commercial speech, noncommercial speech and debate on an issue of public importance." Id. at 663 (Stevens, J., concurring).

12. This Article focuses only on the communications between websites that form the initial relationship that is, advertisements and the website's Terms of Service and posted privacy policies. This Article does not intend to address the use of personal data by various online actors after a relationship is formed with a user. Numerous scholars have dealt ably with the First Amendment issues attendant to data privacy. See, e.g., Neil M. Richards, Reconciling Data Privacy and the First Amendment, 52 UCLA L. Rev. 1149 (2005); Eugene Volokh, Freedom of Speech and Information Privacy: The Troubling Implications of a Right to Stop People from Speaking About You, 52 STAN. L. REv. 1049 (2000).

13. See supra note 1 and accompanying text; infra notes 182-84 and accompanying text.

14. Authors have warned against the danger of an expanded definition of commercial speech. See, e.g., Bruce E.H. Johnson \& Ambika K. Doran, Amendment XXVIII? Defending Corporate Speech Rights, 58 S.C. L. REv. 855, 857 (2007); Elliott L. Dozier, Note, Kasky v. Nike: The Effect of the Commercial Speech Classification on Corporate Statements, 33 STETSON L. REV. 1035, 1038 (2004).

15. See generally TAmara R. Piety, BRAndishing the First Amendment, COMMERCIAL EXPRESSION IN AMERICA (2012) (examining the dangers of treating commercial speech as fully protected speech); Daniel J.H. Greenwood, Essential Speech: Why Corporate Speech Is Not Free, 83 IowA L. REv. 995 (1998) (arguing against treating corporate speech as fully protected). 
necessary information, ${ }^{16}$ and the interests in making sure that corporate players (even those offering free services) are on a level playing field with their competitors make defining the scope of the commercial speech doctrine a critical task. ${ }^{17}$

If only speech that proposes a direct fee-for-service transaction between a product's creator and the product's user is considered commercial speech, much of the current regulation of companies like Google and Facebook would be subject to the more stringent limitations of non-commercial speech regulation. ${ }^{18}$ The ramifications of such an outcome are troubling. ${ }^{19}$

Over the past several years, there has been a rising tide of unease regarding the potential use (or misuse) of user information by Facebook, Google, and other free service Internet companies. ${ }^{20}$ Consumers, legal scholars, and privacy advocates have demanded more restrictive policies on the use of such information ${ }^{21}$ and more stringent government regulation of breaches of privacy policies. ${ }^{22}$ Underlying these calls for action is an as-

16. Va. State Bd. of Pharmacy v. Va. Citizens Consumer Council, Inc., 425 U.S. 748, 763-64 (1976). In establishing the commercial speech doctrine, the main concern of the Court was not simply, nor even primarily, for the speaker proposing the commercial transaction. See id. Rather, the Court was clearly stressing the interest of both the particular consumer and society as a whole in the free flow of commercial information. See id.

17. See James Weinstein, Speech Categorization and the Limits of First Amendment Formalism: Lessons from Nike v. Kasky, 54 CASE W. RES. L. REv. 1091 (2004) (considering the difficulty and importance of categorizing speech); Erwin Chemerinsky \& Catherine Fisk, What Is Commercial Speech? The Issue Not Decided in Nike v. Kasky, 54 CASE W. RES. L. REV. 1143, 1147-50 (2004) (considering the line between commercial and non-commercial speech).

18. See infra Sections II.B-C.

19. See infra Sections II.B-C.

20. Daniel Ionescu, Facebook Privacy Fail: Apps Leak Private Info, Report, PCWORLD (Oct. 18, 2010, 6:18 AM), http://www.pcworld.com/article/208058/ facebook privacy_fail_apps_leak_private_info_report.html; Google Privacy Changes 'In Breach of EU Law, 'BBC News (Mar. 1, 2012, 10:00 AM), http://www.bbc.co.uk/news/technology17205754.

21. See David Sarno, 'Do Not Track Me Online' Privacy Bill Introduced by California Rep. Jackie Speier, L.A. TimEs (Feb. 11, 2011, 10:18 AM), http://atimesblogs.latimes.com/technology/2011/02/do-not-track-me-online-privacylegislation-introduced-by-calif-congresswoman.html; THE WHITE HOUSE, CONSUMER DATA Privacy in a Networked World: A Framework for Protecting Privacy and Promoting InNovation IN THE Global Digital Economy (2012), available at http:/www.whitehouse.gov/sites/default/files/privacy-final.pdf; Benny Evangelista, Search Engine Users Worry About Privacy Invasion, SFGATE (Mar. 9, 2012, 12:40 PM), http://blog.sfgate.com/techchron/2012/03/09/search-engine-users-worry-about-privacyinvasion/.

22. See Jon Brodkin, Consumer Groups Hammer Facebook Privacy Violations in Federal Complaint, PCWORLD (May 6, 2010, 6:10 PM), http://www.pcworld.com/article/195818/Facebook.html; Molly Jennings, To Track or Not To Track: Recent Legislative Proposals to Protect Consumer Privacy, 49 HARV. J. ON LEGIS. 193 (2012); Fed. Trade Comm'n, Protecting Consumer Privacy in an Era of Rapid 
sumption that the government can require companies that provide free services to publish privacy policies-and that the government can punish companies for breaching their stated policies.

Let us imagine, for example, that Facebook were to publish to its users a policy with regards to its use of private user information. ${ }^{23}$ Furthermore, imagine that Facebook's website promoted its strict privacy policy on the sign up page for new users. ${ }^{24}$ Should local, state, or federal regulators be able to enforce this policy? Should they even be able to compel that such a policy be posted or formulated? Thus far, not only commentators but also regulators ${ }^{25}$ - and even, to an extent, Facebook itself ${ }^{26}$ - have answered this question in the affirmative.

Likewise, imagine that Google aggressively promoted its Google+ product through television advertisements that contained false and misleading statements about the capabilities of Google+. Would such advertisements be subject to regulation by state or local prohibitions on false and misleading advertising? Although one's instinct might be to answer in the affirmative, because consumers pay nothing for the Google+ service, ${ }^{27}$ current First Amendment doctrine might suggest that the less stringent standards applicable to the regulation of commercial speech would not be a good fit.

Given that both the regulators and, to an extent, the regulated companies believe that their speech directed at non-paying users is able to be regulated without meeting the exacting First Amendment standards afforded to non-commercial speech, perhaps the error is not that the assumption is wrong, but rather that the current contours of the commercial speech doctrine have become outdated.

Change: A Proposed Framework for Businesses and Policymakers (2010), available at http://www.ftc.gov/os/2010/12/101201privacyreport.pdf.

23. It does. Data Use Policy, FACEBOOK, http://www.facebook.com/about/privacy/ (last visited Apr. 8, 2013).

24. Id. (showing that the Facebook "Data Use Policy," which explains the privacy policy, is provided via hyperlink directly below the sign-up for a Facebook account: "By clicking Sign Up, you agree to our Terms and that you have read our Data Use Policy ....").

25. Complaint, Facebook, Inc., No. 092-3184 (Fed. Trade Comm'n 2012) (No. C4365), 2012 WL 3518628, available at http://www.ftc.gov/os/caselist/0923184/111129facebookcmpt.pdf [hereinafter Complaint, Facebook, Inc.].

26. Somini Sengupta, F.T.C. Settles Privacy Issue at Facebook, N.Y. TimES, Nov. 30,2011 , at B1 (submitting to regulation of the F.T.C. via settlement).

27. See Google Terms of Service, GOOGLE, https://www.google.com/intl/en/policies/terms/ (last visited Apr. 8, 2013) (indicating that its Terms of Service include no charges); Create a New Google Account, Google, https://accounts.google.com/SignUp? service $=$ oz\&continue=https://plus.google.com $/$ ?gpcaz $\%$ 3D8c39f574\&hl=en-US (last visited Apr. 8, 2013) (requiring users to create a free Google Account to sign up for Googlet). 
This Article addresses the tension between the current commercial speech test and the rise of business models in which companies do not charge users directly for their products, and proposes two alternate commercial speech tests as solutions to this problem. In Part I, the Article discusses the current test for commercial speech and its implied reliance on a direct economic transaction between the consumer and the speaker/company. In Part II, the Article examines the rise of business models that do not rely on a fee-for-service transaction and the complexities of applying the current commercial speech test to those businesses. In Part III, the Article explores two alternate commercial speech tests - one from the consumer perspective $^{28}$ and the other from the business perspective ${ }^{29}$ - that will allow the doctrine to adjust to the advent of new business models. Although the consumer-oriented model of determining whether speech is commercial may perhaps solve the "problem" of new business models, a business-focused test that examines whether an entity was "selling against" its users in determining whether speech is commercial has not to date been proposed. We propose a fresh definition of "commercial transaction" that takes into account the Internet economy and other indirect financial exchanges. By including transactions where a company leverages consumer participation as a saleable good, the commercial speech doctrine can remain effective and vital in today's digital age.

\section{COMMERCIAL SPEECH AND THE CONSUMER}

\section{A. The Development of the Commercial Speech Doctrine}

Like the Internet, ${ }^{30}$ the commercial speech test is a creature of relatively recent pedigree. Though the Supreme Court has addressed this doctrine relatively frequently over the past few decades, it seems clear from the Court's body of commercial speech jurisprudence that its concept of what constitutes a commercial transaction is based on an overly simple-and perhaps outdated-notion of commerce. Just as some have noted the Court's slowness to adapt constitutional doctrine to new technology in the

28. See Robert Post, The Constitutional Status of Commercial Speech, 48 UCLA L. REV. 1, 55-57 (2000) (recognizing the listener's interest as substantial in the commercial context).

29. See Greeley, supra note 6 (explaining that when individuals use free online services, they are supplying the providers with information that is then sold "to the companies of the Digital Advertising Alliance," the actual customers).

30. Although there is some controversy about when the Internet was created, the term "Internet" may have first been used in 1974 by Vinton Cerf and Robert Kahn in a paper on Transmission Control Protocol. GARY P. SCHNEIDER \& JessiCa EVANS, THE INTERNET app. at 13 (7th ed. 2009). 
Fourth Amendment context, ${ }^{31}$ it seems that the commercial speech doctrine has not necessarily taken the web economy into account, despite coming of age with the Internet.

Protection under the commercial speech doctrine first arose just thirtyseven years ago in Virginia State Board of Pharmacy v. Virginia Citizens Consumer Council, Inc. ${ }^{32}$ At the time, past decisions of the Court had suggested that commercial speech was unprotected,$^{33}$ and this was the first time the issue of "whether there is a First Amendment exception for "commercial speech" was "squarely before" the Court. ${ }^{34}$ It was in this first venture of offering commercial speech First Amendment protection that the Court constrained its vision of what constitutes commercial speech for all subsequent cases. Framing the question before it as "whether speech which does 'no more than propose a commercial transaction' ... lacks all protection," ${ }^{35}$ the Court, perhaps unintentionally, offered up this vision as the definition of what constitutes commercial speech.

As the commercial speech doctrine continued to develop, it became apparent that the framing question of Virginia State Board of Pharmacy had constrained the understanding of what constitutes commercial speech. Echoing Virginia State Board of Pharmacy, Bolger v. Youngs Drug Products Corp. identifies the "core notion of commercial speech [as] 'speech which

31. Jay Stanley, The Crisis in Fourth Amendment Jurisprudence 1 (2010), available at http://www.acslaw.org/files/ACS\%20Issue $\% 20 \mathrm{Brief} \% 20$ $\% 20$ Stanley\%204th\%20Amendment.pdf (noting that "courts are particularly slow in adapting our traditions to new technologies ... [such that] [i]t took almost 40 years for the Supreme Court to recognize that the Constitution should apply to the wiretapping of telephone conversations"); see also Frederick Schauer, Institutions as Legal and Constitutional Categories, 54 UCLA L. REV. 1747, 1762 (2007) (noting generally that "legal doctrine, typically in the service of the frequently desirable values of stability and predictability, is itself often slow to adapt to changes in the external world").

32. 425 U.S. 748 (1976).

33. See Breard v. Alexandria, 341 U.S. 622 (1951) (upholding a conviction for a violation of ordinance prohibiting door-to-door solicitation of magazine subscriptions); Valentine v. Chrestensen, 316 U.S. 52, 54 (1942) (finding that the First Amendment prevented the government from banning all communication by handbill but imposed "no such restraint on government [with] respect[ to] purely commercial advertising").

34. Va. State Bd. of Pharmacy, 425 U.S. at 760-61. In the previous term, the Court had determined in Bigelow v. Virginia that a conviction under a Virginia statute for advertising the availability of abortions in New York could not stand. 421 U.S. 809, 811-12, 829 (1975). Notably, in that case the Court did not determine the status of commercial speech, but noted that the advertisement at issue "did more than simply propose a commercial transaction. It contained factual material of clear 'public interest."' Id. at 822 . It is interesting to consider whether and why the Court determined the advertising of abortions was a matter in the public interest but determined the advertising of another medical service, distribution of prescription drugs, was simply a question of commercial interest. See id. at 811-12, 829; $\mathrm{Va}$. State Bd. of Pharmacy, 425 U.S. at 750, 760-61.

35. Va. State Bd. of Pharmacy, 425 U.S. at 762 (quoting Pittsburgh Press Co. v. Pittsburgh Comm'n on Human Relations, 413 U.S. 376, 385 (1973)). 
does no more than propose a commercial transaction. ${ }^{,{ }^{36}}$ Bolger, oft cited for what falls into the commercial speech category versus fully protected speech, ${ }^{37}$ notably considers "informational pamphlets" that could not "be categorized merely as proposals to engage in commercial transactions." 38 Bolger is otherwise a rather unremarkable commercial speech case. Though not uniformly thought of in this way, Bolger should perhaps be considered most notable not for its recitation of the "no more than propose" definition, but for its determination that speech that speech not directly proposing a commercial transaction should be analyzed under the commercial speech doctrine..$^{39}$ It is conceivable that little attention was paid to this distinction because the statute in question was found unconstitutional even under the less exacting commercial speech standard. ${ }^{40}$ It is worthwhile to note, however, that at some point in the development of the commercial speech doctrine, the Court was willing to assess speech that did not directly propose a commercial transaction under the commercial speech test based on the surrounding circumstances.$^{41}$ The Court identified three characteristics applicable to determining that these informational pamphlets constituted commercial speech, noting that it was "[t]he combination" of the characteristics that supported the conclusion. ${ }^{42}$ These were (1) the concession that the pamphlets were advertisements; (2) the reference to a specific product; and (3) that there was an economic motivation in mailing the pamphlets. ${ }^{43}$ The Court noted that none of these reasons would alone be sufficient to turn the mailings into commercial speech, but that taken together they "provide[d]

36. Bolger v. Youngs Drug Prods. Corp., 463 U.S. 60, 66 (1983) (quoting Va. State Bd. of Pharmacy, 425 U.S. at 762 ).

37. Many cases cite to Bolger for a definition of commercial speech as doing "'no more than propos[ing] a commercial transaction."' See, e.g., Wag More Dogs, L.L.C. v. Cozart, 680 F.3d 359, 369 (4th Cir. 2012) (citing Bolger, 463 U.S. at 66); Hilton v. Hallmark Cards, 599 F.3d 894, 905 n.7 (9th Cir. 2010) (quoting Hoffman v. Capital Cities/ABC, Inc., 255 F.3d 1180, 1184 (9th Cir. 2011) (quoting Bolger, 453 U.S. at 66)); City of Cincinnati v. Discovery Network, Inc., 507 U.S. 410, 422 (1993) (quoting Bolger, 463 U.S. at 66); S.O.C., Inc. v. County of Clark, 152 F.3d 1136, 1143 (9th Cir.), amended by 160 F.3d 541 (9th Cir. 1998) (quoting Bolger, 463 U.S. at 66).

38. Bolger, 463 U.S. at 66.

39. Id. (quoting Va. State Bd. of Pharmacy, 425 U.S. at 762); Id. at 66 n.13, 67-68. One of the pamphlets in question repeatedly discussed condoms, but without reference to the manufacturer's brands. Id. at $66 \mathrm{n} .13$. "The only reference to appellee's products is contained at the very bottom of the last page, where appellee is identified as the distributor of Trojanbrand prophylactics." Id.; see also Kasky v. Nike, Inc., 45 P.3d 243 (Cal. 2002) (using Bolger in just this way).

40. See Bolger, 463 U.S. at $66,75$.

41. See id. at 66 .

42. Id. at 67 .

43. Id. at 66-67. 
strong support for the ... conclusion that the informational pamphlets are properly characterized as commercial speech." 44

The threshold question of what actually constitutes commercial speech is critical, especially because the treatment of speech once this first hurdle is passed is so different from the treatment of speech that is fully protected under the First Amendment. Determining what speech falls into and out of commercial speech's purview-and for the speech that is not commercial, whether that speech is instead entitled to full First Amendment protection or is outside the protection of the Amendment entirely - is virtually the entire ball game when it comes to upholding government speech regulations in this area. ${ }^{45}$

The test that is applied once the speech in question is determined to be commercial was set out in Central Hudson Gas \& Electric Corp. v. Public Service Commission of New York. ${ }^{46}$ In examining a ban on advertising by a utility company, the Court outlined the parameters for testing the validity of regulations on commercial speech. ${ }^{47}$ Central Hudson spawned a four-part test that now bears its name in commercial speech litigation and case law: (1) the speech must be "protected by the First Amendment," that is, "it at least must concern lawful activity and not be misleading"; and (2) the court will assess "whether the asserted governmental interest is substantial." 48 Upon answering both of these questions in the affirmative, the court looks to (3) "whether the regulation directly advances the governmental interest asserted," and (4) "whether it is not more extensive than is necessary to serve that interest." ${ }^{\text {"49 }}$ In establishing this test, the Court remained conscious that one of the important interests underlying the protection of commercial speech at all is to "assist[] consumers and further[] the societal interest in the fullest possible dissemination of information." ${ }^{50}$ Even in considering advertising that "communicates only an incomplete version of the relevant facts," the Court still was thinking in terms of government prohibitions on

44. Id. at 67.

45. In litigation, governments sometimes must all but concede that the regulation in question would not survive a review under strict scrutiny and instead focus their entire litigation strategy on fighting to keep the speech in question within the category of commercial speech. See, e.g., Brief of Defendants-Appellees, Dex Media West, Inc. v. City of Seattle, 696 F.3d 952 (9th Cir. 2012) (Nos. 11-35787, 11-35399), 2011 WL 6980707 (spending the bulk of the brief arguing that Yellow Pages were in fact commercial speech). Empirical analysis demonstrates that although the "famous adage ['strict in theory, fatal in fact'] arose in the context of equal protection, strict scrutiny is actually most fatal in the area of free speech." Adam Winkler, Fatal in Theory and Strict in Fact: An Empirical Analysis of Strict Scrutiny in the Federal Courts, 59 VAND. L. REv. 793, 807, 844 (2006).

46. 447 U.S. 557 (1980).

47. Id. at 566 .

48. Id.

49. Id.

50. Id. at 561-62. 
speech, noting, "the First Amendment presumes that some accurate information is better than no information at all." 51

The deep difference in the treatment of commercial versus noncommercial speech can be aptly illustrated by the first step of the Central Hudson test. The first prong requires that the speech "must concern lawful activity and not be misleading." 52 If the speech, already defined as commercial through the definitional test considered in Virginia State Board of Pharmacy and Bolger, does not meet these two elements of the first prong of the Central Hudson test, it no longer has recourse to any of the protections of the First Amendment. ${ }^{53}$ This status is striking in its difference from the treatment of non-commercial speech, where the truth-value of the speech does not determine the level of protection afforded to the speech. ${ }^{54}$ In the recent case, United States v. Alvarez, where the Court held that a federal statute criminalizing false speech related to claims of military service was unconstitutional under the First Amendment as a content-based restriction, the Court pointed to Virginia State Board of Pharmacy for the proposition that fraudulent speech falls outside of the protection of the First Amendment. ${ }^{55}$ The Court's citation to Virginia State Board of Pharmacy, however, served to underscore the different understanding the Court has, at this point, for commercial versus non-commercial speech. ${ }^{56}$ The language of the decision in Virginia State Board of Pharmacy seemed more expansive (dismissing the idea of protecting false speech in general) than what it was cited for or what was eventually held in Alvarez. ${ }^{57}$ The holding in Alvarez,

51. Id. at 562 (citing Bates v. State Bar of Ariz., 433 U.S. 350, 374 (1977)).

52. Id. at 566 .

53. Id. at 561, 566; Bolger v. Youngs Drug Prods. Corp., 463 U.S. 60, 66 (1983).

54. United States v. Alvarez, 132 S. Ct. 2537, 2546-47 (2012) (indicating the decision "rejects the notion that false speech should be in a general category that is presumptively unprotected"); see also id. at 2542, 2547-48 (holding that a statute criminalizing false speech related to claims of military service "would endorse government authority to compile a list of subjects about which false statements are punishable. That governmental power has no clear limiting principle.... Were this law to be sustained, there could be an endless list of subjects the National Government or the States could single out. ... Were the Court to hold that the interest in truthful discourse alone is sufficient to sustain a ban on speech, absent any evidence that the speech was used to gain a material advantage, it would give government a broad censorial power unprecedented in this Court's cases or in our constitutional tradition. The mere potential for the exercise of that power casts a chill, a chill the First Amendment cannot permit if free speech, thought, and discourse are to remain a foundation of our freedom").

55. Id. at $2542-43,2545,2547$.

56. See id. at 2547 (citing Va. State Bd. of Pharmacy v. Va. Citizens Consumer Council, Inc., 425 U.S. 748, 771 (1976)).

57. Va. State Bd. of Pharmacy, 425 U.S. at 771 ("Untruthful speech, commercial or otherwise, has never been protected for its own sake."); Alvarez, $132 \mathrm{~S}$. Ct. at 2547 (stressing that Virginia State Board of Pharmacy notes that "fraudulent" speech is unprotected by the First Amendment). 
especially when juxtaposed against the first prong of the Central Hudson test, underscores the difference between commercial and non-commercial speech, and thus, the importance of capturing the speech in which there is the strongest interest in regulating when constructing the definition of commercial speech.

The importance of capturing all of the speech that we would want to be regulated as commercial speech was made even more salient by the Court's further clarification of the Central Hudson test. The fourth prong, which demands that the regulation be no "more extensive than is necessary to serve [the asserted government] interest," out the ensuing decade as being equivalent to demanding the regulation be the "least restrictive measure." 59 This understanding of the fourth prong would amount to commercial speech having comparable or even greater protection than non-commercial speech in some situations. Realizing this discontinuity, the Court rejected the interpretation of the fourth prong as requiring the regulation be the least restrictive approach. ${ }^{60}$ Acknowledging that its own previous dicta assumed the fourth step of Central Hudson was synonymous with "the "least-restrictive-means' approach," pressly addressed the question and determined that the test "requires something short of a least-restrictive-means standard." ${ }^{62}$ Noting that they had not even required this standard in cases "where core political speech is at issue," 63 the Court set the standard at "a means narrowly tailored to achieve the desired objective. Within those bounds we leave it to governmental decisionmakers to judge what manner of regulation may best be employed." ${ }^{64}$ Thus, the refinement of the fourth prong of the Central Hudson test creates a real difference between whether protection for commercial or non-commercial speech is applied-and makes identifying the correct threshold markers all the more important.

58. Cent. Hudson, 447 U.S. at 566.

59. See, e.g., Bd. of Trs. of State Univ. of N.Y. v. Fox, 492 U.S. 469, 476 (1989) ("We have indeed assumed in dicta the validity of the 'least-restrictive-means' approach."); Zauderer v. Office of Disciplinary Counsel, 471 U.S. 626, $651 \mathrm{n} .14$ (1985) (noting that while the Court used the "least restrictive means" test in assessing commercial speech, a different test is needed for disclosure regulations); Fox v. Bd. of Trs. of State Univ. of N.Y., 841 F.2d 1207, 1214 (2d Cir. 1988); Sambo's Rests., Inc. v. City of Ann Arbor, 663 F.2d 686, 693 (6th Cir. 1981).

60. Fox, 492 U.S. at 480 . There still seems to be some confusion among the courts as to whether the least restrictive approach test plays a part in evaluating the regulation of commercial speech. See United States v. Caronia, 703 F.3d 149, 167 (2d Cir. 2012) (vacating a criminal conviction for off-label drug marketing, noting that "[n]umerous, less speechrestrictive alternatives are available, as are non-criminal penalties").

61. Fox, 492 U.S. at 476.

62. Id. at 477 .

63. Id.

64. Id. at 480 . 
While for a period the posited intermediate scrutiny appeared much more like rational basis review, ${ }^{65}$ as the decades have progressed, commercial speech has found substantial protection from the courts. ${ }^{66}$ Most notably, the Court's most recent commercial speech case appeared to muddle the accepted understanding of commercial speech and application of the Central Hudson test, thus causing consternation among regulators and academics, and even in half of the Court. ${ }^{67}$

Sorrell v. IMS Health Inc. dealt with a challenge by data miners and pharmaceutical manufacturers against Vermont's Prescription Confidentiality Law, which placed restrictions upon the sale, disclosure, and use of pharmacy records that displayed the prescribing practices of physicians within the State. ${ }^{68}$ At issue in IMS Health was the pharmaceutical marketing practice known as "detailing," whereby pharmacies, who receive "prescriber-identifying information" when processing prescriptions, sell that information to data-miners, who then produce reports on doctors' prescribing

65. See Posadas de P.R. Assocs. v. Tourism Co. of P.R., 478 U.S. 328 (1986); United States v. Edge Broad. Co., 509 U.S. 418 (1993). In Posadas, the Court upheld a regulation that prohibited advertising by casinos to Puerto Rican residents. Posadas, 478 U.S. at 348. In Edge Broadcasting, building on its decision in Fox, in assessing a ban on lottery advertising by broadcasters in states where the lottery is illegal, the Court "concluded that the validity of restrictions on commercial speech should not be judged by standards more stringent than those applied to expressive conduct entitled to full First Amendment protection or to relevant time, place, or manner restrictions." Edge Broad. Co., 509 U.S. at 428-29. Rather, "commercial speech cases require a fit between the restriction and the government interest that is not necessarily perfect, but reasonable." Id. This pair of cases perhaps muddled the Central Hudson test more than clarified it. As the dissent in Posadas noted, prior to that case, the Court had "consistently invalidated restrictions designed to deprive consumers of accurate information about products and services legally offered for sale." Posadas, 478 U.S. at 350 (Brennan, J., dissenting). And in Edge Broadcasting, the regulated radio station at issue actually reached more people in the state where the lottery was legal rather than in its licensing state. Edge Broad. Co., 509 U.S. at 429. The outcome in Edge Broadcasting left some wondering about the extent of the fit required between the government interest and the restriction. Perhaps Posadas and Edge Broadcasting can be dismissed as only applying in the case of gambling, a long recognized social ill. However, neither case holds up the subject matter as the primary motivation underlying the decision, nor do the cases claim to set out a different test in the gambling context. These cases marked, perhaps, the low point of protection for commercial speech, but the Court returned to greater protections just three years after Edge Broadcasting. 44 Liquormart, Inc. v. Rhode Island, 517 U.S. 484 (1996).

66. See 44 Liquormart, 517 U.S. at 489 (holding that a ban on price advertising of alcohol was unconstitutional under the First Amendment).

67. Sorrell v. IMS Health Inc., 131 S. Ct. 2653, 2677 (2011) (Breyer, J., dissenting) ("Thus, it is not surprising that, until today, this Court has never found that the First Amendment prohibits the government from restricting the use of information gathered pursuant to a regulatory mandate - whether the information rests in government files or has remained in the hands of the private firms that gathered it. ... Nor has this Court ever previously applied any form of 'heightened' scrutiny in any even roughly similar case.").

68. See id. at 2659 (majority opinion). 
behavior and sell that information to pharmaceutical manufacturers. ${ }^{69}$ The law at issue mandated that this prescriber information "may not be sold, disclosed by pharmacies for marketing purposes, or used for marketing by pharmaceutical manufacturers." 70 The majority and dissenting opinions had entirely different views of the speech in question, and the outcome of the case left many questioning the continued viability of the commercial speech doctrine. ${ }^{11}$ The majority held, "Speech in aid of pharmaceutical marketing [] is a form of expression protected by the Free Speech Clause of the First Amendment" and is thus subject to heightened scrutiny. ${ }^{72}$ Even though the law in question only regulated information for use in commercial transactions, the Court determined that the state law amounted to both contentbased and speaker-based restrictions. ${ }^{73}$ It is clear that from the Court's focus on the content-based nature of the Vermont law that commercial speech analysis was not considered as the appropriate mode of analysis, if considered at all. ${ }^{74}$ In what was perhaps most shocking to commentators, the majority opinion contains only one reference to Central Hudson, rather than a clear analysis of the statute in question under the four-prong test. ${ }^{75}$

The dissent in IMS Health took an entirely different view of the statute before it. Simply put, for the dissent, the only

effect on expression is inextricably related to a lawful governmental effort to regulate a commercial enterprise. The First Amendment does not require courts to apply a special "heightened" standard of review when reviewing such an effort. And, in any event, the statute meets the First Amendment standard this Court has previously applied when the government seeks to regulate commercial speech. ${ }^{76}$

These two visions of the speech in question in IMS Health are entirely divergent and thus leave many commentators scratching their heads at what

69. Id. at $2659-60$.

70. Id. at 2659 .

71. See Kevin Outterson, Higher First Amendment Hurdles for Public Health Regulation, 365 NEW ENG. J. MED. e13 (2011), available at $\mathrm{http} / /$ www.nejm.org/doi/full/10.1056/NEJMp1 107614?viewType=Print. But see Micah Berman, Kathleen Dachille \& Julie Ralston Aoki, Sorrell and the Future of Commercial Speech Regulations, JURIST (Oct. 4, 2011), http://jurist.org/forum/2011/10/berman-dachilleaoki-sorrell.php (asserting that "Sorrell did not break any new legal ground").

72. IMS Health, $131 \mathrm{~S}$. Ct. at 2659.

73. Id. at 2663. All commercial speech analyses are necessarily content based, as they rest on a determination of whether the speech's content proposes a commercial transaction. See, e.g., J.M. Balkin, Some Realism About Pluralism: Legal Realist Approaches to the First Amendment, 1990 DUKE L.J. 375, 396 ("arguing that 'obscenity, commercial speech, and 'fighting words" must be outside the category of "speech" if content neutrality is mandatory.").

74. IMS Health, $131 \mathrm{~S}$. Ct. at 2663-64.

75. Id. at 2668 .

76. Id. at 2673 (Breyer, J., dissenting). 
constitutes commercial speech. ${ }^{77}$ Despite the apparent new "content" analysis of IMS Health, the case underscores the importance of the definitional question of what constitutes commercial speech. ${ }^{78}$ The data exchange in question appeared to be wholly commercial-the very stuff of a commercial transaction. ${ }^{79}$ For the majority of the Court, however, as their content-based analysis highlights, the statute was not regulating commercial speech, that is, speech that "does 'no more than propose a commercial transaction."

In addition to having a clear understanding of the legal doctrine that applies to commercial speech, it is important to also keep an eye on the values the Court was aiming to protect when setting up this relatively new doctrine. In establishing that commercial speech was not devoid of protection under the First Amendment, the Court looked to the interest of both the speaker and the listener, determining that a "particular consumer's interest in the free flow of commercial information ... may be as keen, if not keener by far, than his interest in the day's most urgent political debate." ${ }^{81}$ The Court generalized this interest to be one of society at large and notes that in maintaining "a predominantly free enterprise economy, ... the free flow of commercial information is indispensable." ${ }^{22}$ In establishing that commercial speech was not devoid of First Amendment protection, the Court was careful to note that this did not mean that no regulation of commercial speech could stand, rather " $[w]$ hat [was] at issue [was] whether a State may completely suppress the dissemination of concededly truthful information about entirely lawful activity." ${ }^{83}$ It is notable that the first foray of commercial speech into the constitutional realm dealt with attempts by the government to prevent consumers from having price information. ${ }^{84}$ Rather quickly it became a clash that has turned this set of interests on its head: the government wishes to compel retailers and other commercial speakers to give consumers certain information, and these speakers claim protection from such compulsion-using the doctrine that was initially concerned with ensuring

77. See, e.g., Jedediah Purdy, The Roberts Court v. America, Democracy, Winter 2012, at 46, 50-51; Marcia M. Boumil, Pharmaceutical Gift Laws and Commercial Speech Under the First Amendment in the Wake of Sorrell v. IMS Health, Inc., 8 J. HEaLtH \& BIOMEDICAL L. 133, 162-70 (2012); David Gans, Sorrell v. IMS Health: Corporate Commercial Speech in the Age of Citizens United, Balkinization (June 23, 2011, 6:33 PM), http://balkin.blogspot.com/2011/06/sorrell-v-ims-health-corporate.html.

78. See Purdy, supra note 77 , at $49-51$.

79. Id. at 50.

80. Va. State Bd. of Pharmacy v. Va. Citizens Consumer Council, Inc., 425 U.S. 748, 762 (1976) (quoting Pittsburgh Press Co. v. Pittsburgh Comm'n on Human Relations, 413 U.S. 376,385 (1973)).

81. Id. at 763 .

82. Id. at 765 .

83. Id. at 773 .

84. Id. at $759-60$ 
consumers were equipped with the commercial information in which they were likely interested.

An important parallel branch of the commercial speech doctrine came into being in Zauderer v. Office of Disciplinary Counsel of the Supreme Court of Ohio. ${ }^{85}$ Here, the Court considered regulations on attorney advertising. While striking down several of the prohibitions under the commercial speech doctrine as already discussed, the Court took a different view of the law that required certain disclosures to be made in the advertisements. ${ }^{86}$ Noting the "material differences between disclosure requirements and outright prohibitions on speech," ${ }^{87}$ the Court found a real distinction between a statute that prevented attorneys "from conveying information to the public" and one that "required them to provide somewhat more information than they might otherwise be inclined to present." ${ }^{18}$ Identifying a well-informed public as the value underlying any protection for commercial speech ${ }^{89}$ the Court distinguished the statute in question from the compelled speech doctrine the Court had previously laid down in Wooley v. Maynard, ${ }^{90}$ Miami Herald Publishing Co. v. Tornillo, ${ }^{91}$ and West Virginia State Board of Education v. Barnette. ${ }^{92}$ Instead of applying the "not more extensive" test of Central Hudson, ${ }^{93}$ the Court held that "an advertiser's rights are adequately protected as long as disclosure requirements are reasonably related to the State's interest in preventing deception of consumers." 94

Examining a series of regulations that governed solicitation of charitable contributions, the Court distinguished Zauderer from Riley v. National

85. 471 U.S. 626, 651 (1985).

86. Id. at $650-53$.

87. Id. at 650 .

88. Id.

89. Id. at 651 .

90. 430 U.S. 705 (1977).

91. 418 U.S. 241 (1974).

92. 319 U.S. 624 (1943).

93. Cent. Hudson Gas \& Elec. Corp. v. Pub. Serv. Comm'n, 447 U.S. 557, 566 (1980).

94. Zauderer, 471 U.S. at 651 . It remains unanswered whether the only appropriate interest to support a state mandated disclosure in the commercial context is the prevention of deception. Preventing deception was the particular interest asserted by the state in Zauderer and in the more recent, Milavetz, Gallop \& Milavetz, P.A. v. United States, 130 S. Ct. 1324, 1340-41 (2010). Other courts have considered such compelled disclosure requirements where the state asserted another interest than the prevention of deception, and the Court accepted this interest and used the Zauderer test to determine the viability of the law. See N.Y. State Rest. Ass'n v. N.Y.C. Bd. of Health, 556 F.3d 114, 133 (2d Cir. 2009); Pharm. Care Mgmt. Ass'n v. Rowe, 429 F.3d 294, 310 n.8 (1st Cir. 2005); Envtl. Def. Ctr., Inc. v. EPA, 344 F.3d 832, 849-50 (9th Cir. 2003); Nat'l Elec. Mfrs. Ass'n v. Sorrell, 272 F.3d 104, 114-15 (2d Cir. 2001). 
Federation of the Blind of North Carolina, Inc. ${ }^{95}$ In assessing a regulation that required professional solicitors to disclose the fact that they were paid professionals to potential donors, the State argued that regardless of the protected status of charitable donations in general, the disclosure portion "regulate[d] only commercial speech because it relate[d] only to the professional fundraiser's profit from the solicited contribution." ing whether the speech identifying the speaker as a paid professional would alone constitute commercial speech, the Court laid out its "inextricably intertwined" test, thus insulating mixed commercial and non-commercial speech. ${ }^{97}$ The Court noted, "we do not believe that the speech retains its commercial character when it is inextricably intertwined with otherwise fully protected speech." ${ }^{\text {98 }}$ In Riley, the Court determined that the protected charitable solicitation was entwined with a report on the status of the solicitors to such a degree that the two could not be pulled apart. "[W]here, as here, the component parts of a single speech are inextricably intertwined, we cannot parcel out the speech, applying one test to one phrase and another test to another phrase. Such an endeavor would be both artificial and impractical." 99

\section{B. The Definitional Struggle Surrounding Commercial Speech}

The literature surrounding the commercial speech doctrine often revolves around the level of protection such speech should receive. But regardless of one's position on this question, an antecedent question, one that indeed occupies much of the scholarship in this area, must first be answered-what constitutes commercial speech? This definitional question must be answered not only in order to determine what speech deserves protection, but also to grasp the values that underlie the decision to protect certain speech as "commercial" while granting other speech the full protections of the First Amendment. ${ }^{100}$

The definition most often pointed to, as discussed in the previous Section, is that commercial speech is speech that "does 'no more than propose a

95. 487 U.S. 781,796 n.9 (1988) (citing Zauderer, 471 U.S. at 626) ("Purely commercial speech is more susceptible to compelled disclosure requirements.").

96. Id. at 795 .

97. Id. at 796 .

98. Id. Notable is the fact that this is almost the exact opposite conclusion that the Court came to in Bolger v. Youngs Drug Prods. Corp., 463 U.S. 60, 66-67 (1983).

99. Riley, 487 U.S. at 796.

100. For an excellent discussion of this definitional problem, see Tamara R. Piety, " $A$ Necessary Cost of Freedom"? The Incoherence of Sorrell v. IMS, 64 ALA. L. REV. 1, 36-40 (2012). 
commercial transaction."'01 The courts have also referred to commercial speech as that which "relate[s] solely to the economic interests of the speaker and its audience." 102 As the foregoing discussion of the case law demonstrated, however, the actual practice of defining commercial speech at times reaches a broader category of speech. ${ }^{103}$ Moving from the real world application within the case law to the scholarship in this area allows for a focus not only on what actually constitutes commercial speech, but also on what should be included in that category.

From one perspective, the lack of a clear definition setting the bounds of commercial speech makes the commercial/non-commercial distinction all the more dangerous. One argument insists that, in order to justify this distinction, commercial speech can only constitute the most narrow reading arising from Virginia State Board of Pharmacy: "an offer to sell (X) good or service at (Y) price." 104 Others still have insisted that, while perhaps the commercial speech definition was once broader than the "no more than propose a commercial transaction" definition, doctrinal development at the Court has limited the definition to this original description. ${ }^{105}$ Another ar-

101. Va. State Bd. of Pharmacy v. Va. Citizens Consumer Council, Inc., 425 U.S. 748, 762 (1976) (quoting Pittsburgh Press Co. v. Pittsburgh Comm'n on Human Relations, 413 U.S. 376, 385 (1973)).

102. Cent. Hudson Gas \& Elec. Corp. v. Pub. Serv. Comm'n, 447 U.S. 557, 561-62 (1980).

103. Bolger v. Youngs Drug Prods. Corp., 463 U.S. 60, 66-67 (1983).

104. David F. McGowan, A Critical Analysis of Commercial Speech, 78 CALIF. L. Rev. 359, 401 (1990) (citing Va. State Bd. of Pharmacy, 425 U.S. at 761).

105. J. Wesley Earnhardt, Nike, Inc. v. Kasky: A Golden Opportunity to Define Commercial Speech-Why Wouldn't the Supreme Court Finally "Just Do It ${ }^{\mathrm{TM}}$ "?, 82 N.C. L. REv. 797, 803 (2004) (arguing that the cases with a broader definition of commercial speech all predated United States $v$. United Foods, Inc., which offered the " usual[]" definition of commercial speech (quoting United States v. United Foods, Inc., 533 U.S. 405, 409 (2001))). While the Court has not made an explicit pronouncement regarding the definition of commercial speech, Earnhardt's argument may have continuing viability in the current doctrinal environment where many commentators have observed the diminishing distinction between commercial and non-commercial speech. See Jennifer L. Pomeranz, No Need to Break New Ground: A Response to the Supreme Court's Threat to Overhaul the Commercial Speech Doctrine, 45 LoY. L.A. L. REv. 389, 398 (2012) ("The Court has generally become more hostile to commercial speech restrictions along the way."); Tamara R. Piety, Against Freedom of Commercial Expression, 29 CARDozo L. REV. 2583, 2584 (2008) ("[The] trend is to offer broader protection to commercial speech and corporate speakers than has been extended in the past. And it seems likely to culminate in a decision to do away with the distinction between protected commercial speech and other speech protected by the First Amendment."); Kathleen M. Sullivan, Cheap Spirits, Cigarettes, and Free Speech: The Implications of 44 Liquormart, 1996 SuP. Cr. REV. 123, 126 ("After Liquormart, it is unclear why 'commercial speech' should continue to be treated as a separate category of speech isolated from general First Amendment principles."). Additionally, Richard Samp has urged that the most recent commercial speech decision in Sorrell v. IMS Health Inc. calls into question the constitutional validity of numerous speech restrictions created by federal regulations. Richard Samp, Sorrell v. IMS Health: Protecting Free Speech or Resurrecting Lochner?, 2011 CATO 
gument recognizes that this " "no more than propose a commercial transaction" 106 definition "obviously meets any fair conception of commercial speech," ${ }^{107}$ but goes on to argue that the definition is actually broader. ${ }^{108}$ While the "an offer to sell (X) good or service at (Y) price" 109 definition tracks with the most limited definition of commercial speech and appears to conform to perhaps the bulk of the case law, precedent is only built based on the facts of the cases that appear before a court. Professor Steven Shiffrin has further argued that because most of the commercial speech cases have looked at explicit advertising, the definition espoused by the Court and considered by commentators has missed a great deal of the speech that should be defined as commercial simply because these other types of speech were not before the courts in the genesis of the doctrine. ${ }^{110}$

The definition of commercial speech as speech that "relate[s] solely to the economic interests of the speaker and its audience" only slightly different from the definition as "an offer to sell (X) good or service at (Y) price," 12 but this conclusion also depends on how expansive the category of economic interests is defined. In the aftermath of Nike $v$. Kasky, scholars considered why corporations were speaking and considered what mattered to a consumer in making their economic choices. In this context, commercial speech could be defined as "[f]actual statements by a manufacturer to consumers about its products with the objective of increasing sales." ${ }^{\prime 13}$ It is not a stretch to argue that such statements, regardless of

SUP. CT. REV. 129, 139-40. If this observation proves valid, there will be countless "commercial speech" cases before the Court in coming years. Id.

106. Nat Stern, In Defense of the Imprecise Definition of Commercial Speech, 58 MD. L. REv. 55, 79 (1999) (quoting Va. State Bd. of Pharmacy, 425 U.S. at 762).

107. Id.

108. Id. at 89 ("Rather than simplistically lumping together all instances in which a commercial entity speaks or solicitation occurs, the Court has sought to determine whether the content of a communication contains an essential, inextricable dimension of fully protected expression."). 761).

109. McGowan, supra note 104, at 401 (citing Va. State Bd. of Pharmacy, 425 U.S. at

110. Steven Shiffrin, The First Amendment and Economic Regulation: Away from a General Theory of the First Amendment, 78 Nw. U. L. REv. 1212, 1213 (1984) ("Each commercial speech case the Court has considered has involved advertising or the proposal of a commercial transaction, and almost all of the commentators have looked at the 'commercial speech' problem through the lens of commercial advertising. The collective myopia has distorted something quite important: the commercial speech that has been beneath the protection of the first amendment for all these years has not been confined to commercial advertising." (citations omitted)). (1980).

111. Cent. Hudson Gas \& Elec. Corp. v. Pub. Serv. Comm'n, 447 U.S. 557, 561-62

112. McGowan, supra note 104, at 401 (citing Va. State Bd. of Pharmacy, 425 U.S. at 761).

113. Chemerinsky \& Fisk, supra note 17, at 1145. 
their particular subject matter, implicate the economic interests of the speaker. While the economic interests of the audience in this case may be less apparent, it is still plausible that they are indeed implicated. When a consumer makes a choice between products, regardless of the grounds upon which they are making that choice, they implicate economic interests because they are spending money in the economic sphere. That the consumer has chosen to have producers compete on grounds other than product or price does not undermine the fact that the consumer's economic interests are implicated. ${ }^{114}$

A variety of scholars have focused on the values underlying the First Amendment in an effort to construct a coherent picture of what exactly is commercial speech. The contours of commercial speech may be sketched out by identifying that speech which does not fulfill the values-namely, self-government and self-expression-that underlie the First Amendment. ${ }^{115}$ An examination of the motivations underlying the commercial speech doctrine urges that the "distinction [between core and commercial speech] turns on whether constitutional value attaches to participation in a given speech act, or whether constitutional value attaches instead only to the information conveyed by the speech act." 116 When speech does fulfill a core First Amendment value, then that particular speech perhaps cannot be defined as "commercial." 117

Others, in arguing against the separate category of commercial speech, have looked not to the theory underlying that category, but posited that regulation of commercial speech may only be justified if the theoretical question of what disqualifies such speech from the full protection of the First

114. See, e.g., Douglas A. Kysar, Preferences for Processes: The Process/Product Distinction and the Regulation of Consumer Choice, 118 HARv. L. Rev. 525, 531, 584 (2004) (discussing consumers' preference for certain goods not based on price or quality of goods, but upon the processes by which they are created).

115. See, e.g., Piety, supra note 100; Akhil Reed Amar, Intratextualism, 112 HARV. L. Rev. 748, 812-18 (1999); Vincent Blasi, The Pathological Perspective and the First Amendment, 85 Colum. L. Rev. 449, 484-89 (1985); Thomas H. Jackson \& John Calvin Jeffries, Jr., Commercial Speech: Economic Due Process and the First Amendment, 65 VA. L. Rev. 1 (1979); Lillian R. BeVier, The First Amendment and Political Speech, An Inquiry Into the Substance and Limits of Principle, 30 STAN. L. ReV. 299, 352-55 (1978); C. Edwin Baker, Commercial Speech: A Problem in the Theory of Freedom, 62 IowA L. Rev. 1 (1976).

116. Post, supra note 28 , at 20. Post also suggests a method by which to distinguish speech that does not fall within the commercial speech paradigm, not because it is accorded full First Amendment protection, but because it is not considered under the First Amendment: "The doctrine seems to protect only the distribution of commercial information that reinforces a public communicative sphere by addressing strangers who are presumed to be independent and self-possessed. The doctrine stops short of commercial communications between persons deemed to be involved in relationships of dependence or reliance." Id. at 23.

117. See, e.g., Weinstein, supra note 17, at 1111-33 (concluding that speech at issue in Nike v. Kasky has value in terms of democratic decisionmaking). 
Amendment is answered. ${ }^{118}$ This line of thought may even be loath to identify a definition of so-called "commercial speech," as it views this as an illegitimate category - one that should not exist and one that should be replaced by more expansive speech protections for the type of speech contemplated by this Section. ${ }^{119}$

In addition to the effort to define the category based upon constitutional values, there is also an effort to focus the definition of commercial speech based upon consideration of the animating purpose of the doctrine itself. Arising out of the Court's original explanation in Virginia State Board of Pharmacy, ${ }^{120}$ a number of scholars have stressed the value of protecting the free flow of information as the animating principle undergirding the commercial speech doctrine. Some attribute greater public value to this information flow, ${ }^{121}$ while others appear to consider the information as a market necessity. ${ }^{122}$ From the idea of information flow also must arise the recognition of the speech in question having value, not just for the speaker, but importantly for the listeners. ${ }^{123}$

118. See Rodney A. Smolla, Information, Imagery, and the First Amendment: A Case for Expansive Protection of Commercial Speech, 71 TEX. L. REV. 777, 791-93 (1993).

119. Alex Kozinski \& Stuart Banner, Who's Afraid of Commercial Speech?, 76 VA. L. Rev. 627 (1990); Donald E. Lively, The Supreme Court and Commercial Speech: New Words with an Old Message, 72 MINN. L. REv. 289 (1987); Martin H. Redish, The First Amendment in the Marketplace: Commercial Speech and the Values of Free Expression, 39 GEO. WASH. L. REV. 429, 448-58 (1971).

120. Va. State Bd. of Pharmacy v. Va. Citizens Consumer Council, Inc., 425 U.S. 748,765 (1976) ("It is a matter of public interest that those decisions, in the aggregate, be intelligent and well informed. To this end, the free flow of commercial information is indispensable.").

121. See, e.g., Post, supra note 28 , at 4 (arguing that commercial speech "conveys information necessary for public decision making, but that does not itself form part of public discourse").

122. See, e.g., Pomeranz, supra note 105, at 402 ("[E]ssential aspects of the commercial speech doctrine serve society's 'strong interest in the free flow of commercial information' in order to protect and maintain transparent and efficient markets based on 'intelligent and well informed' consumers." (quoting Va. State Bd. of Pharmacy, 425 U.S. at 764$65)$ ).

123. Va. State Bd. of Pharmacy, 425 U.S. at 763 ("As to the particular consumer's interest in the free flow of commercial information, that interest may be as keen, if not keener by far, than his interest in the day's most urgent political debate."); Piety, supra note 100 , at 1 (arguing that the commercial speech "doctrine was not created to protect commercial speakers. It was created to carve out a limited area of First Amendment protection for truthful commercial speech in order to protect consumers' right to receive accurate product information and to thereby promote the public interest in a properly functioning market"); Post, supra note 28 , at 14 ("The Court's development of commercial speech doctrine closely tracks Meiklejohn's analysis. The Court has been quite explicit that commercial speech should be constitutionally protected so as to safeguard the circulation of information. It has therefore focused its analysis on the need to receive information, rather than on the rights of speakers."); Pomeranz, supra note 105, at 404-05 (“" [T] protection to commercial speech is justified principally by the value to consumers of the 
Without a clear definition of commercial speech, there is also the danger of fully protected and not fully protected forms of speech collapsing into one another. Frederick Schauer has flagged the danger of "doctrinal dilution" should heightened First Amendment protection be accorded to commercial speech. ${ }^{124}$ "“[D]octrinal dilution' refers to the possibility that some existing [F]irst $[\mathrm{A}]$ mendment rule would lose some of its strength because of the number of unacceptable applications it would generate when its new applications were added." 125 The danger in moving away from a separate test for commercial speech lies not in the regulation of that speech itself, but in what shifting protections mean for other speech-speech of the kind that most would prefer to see receive heightened First Amendment protection. ${ }^{126}$ William Van Alstyne raises a similar concern, labeled as the choice between leveling up and leveling down. ${ }^{127}$ Recognizing that there have been signals within the doctrine that commercial speech should be subject to the same protections as core political speech, he notes:

information such speech provides,' [so commercial actors'] 'constitutionally protected interest in not providing any particular factual information in his advertising is minimal." (alteration in original) (quoting Zauderer v. Office of Disciplinary Counsel, 471 U.S. 626, 651 (1985))); Jennifer L. Pomeranz, Compelled Speech Under the Commercial Speech Doctrine: The Case of Menu Label Laws, 12 J. Health Care L. \& PoL'y 159, 181 (2009) ("In the commercial marketplace, the emphasis is on the receipt of information by consumers ....").

124. Frederick Schauer, Commercial Speech and the Architecture of the First Amendment, 56 U. CIN. L. ReV. 1181, 1193-97 (1988).

125. Id. at 1194 .

126. Id. at 1194-95. Schauer uses the example of misbranded products and the strictures of the test in Brandenberg v. Ohio. Id. He notes,

There can be no doubt, for example, that some commercial speech is likely to be harmful. Misbranded products are a good example. But restrictions on speech because of its harmfulness, in a system in which speech is protected despite its harmfulness, are normally permissible if and only if the requirements of Brandenburg $v$. Ohio, as further clarified in Hess v. Indiana, are satisfied. And it is clear that whatever the likelihood of harm would be in a misbranded product case, the possibility that the imminence and incitement standards of current law would be satisfied is virtually nonexistent. Thus, were existing first amendment rules to be applied to commercial speech, the choice, in the future development of the law, would be between holding almost all of product misrepresentation law unconstitutional, or of modifying the Brandenburg test so that it would then permit the regulation of misbranded products. It is by no means inconceivable that the Supreme Court, faced with these as the only alternatives, would choose the latter course. The consequence of that, it can be seen, is that Brandenburg, having been weakened to accommodate the inevitable regulability of misbranded products, remains weakened as a protector of the kinds of political argument it was originally designed to protect.

Id. (citations omitted).

127. William Van Alstyne, Remembering Melville Nimmer: Some Cautionary Notes on Commercial Speech, 43 UCLA L. REV. 1635 (1996); see also Pomeranz, supra note 105, at 432-34 (cautioning against "an erosion of the commercial speech doctrine without any serious consideration of its consequences"). 
The choice must be made, that is, either to "level up" commercial speech to the high plateau of core political speech or to "level down" political speech to the low plateau of commercial speech, or perhaps to have them meet somewhere in between. If the one sort of speech is to be acknowledged as "as much within" or "as well within" the First Amendment as the other, these are the evident choices to be made - to unify the standards, and so have them generally treated indistinguishably. ${ }^{128}$

It is apparent from both the case law and the scholarship that the definition of commercial speech is a topic of much disagreement. Within this dialogue are efforts both to describe what commercial speech is, by reference to the way courts have developed the doctrine, as well as to posit what commercial speech should be-claims differently rooted in expanding or contracting the definition. It is against this backdrop that this Article seeks to carve out a space to reach the speech of "free" service providers.

Questions surrounding what is included in the category of commercial speech-and what is left out, either as core speech or as speech not within the First Amendment's ambit-continue to abound. With the seemingly ever-increasing number of Internet and technology companies, new actors are engaging in new forms of speech, which do not fit within traditional categories of commercial and non-commercial speech, but which society may be concerned with regulating. The commercial speech doctrine, though sometimes considered broader than transactional speech, ${ }^{129}$ nonetheless usually hinges on the definition of speech that "does "no more than propose a commercial transaction." 130 In the face of new market models, this concept of a commercial transaction needs to be unpacked.

\section{RISE OF NEW ECONOMY BUSINESS MODELS}

In addition to the already existing definitional struggles in the area of commercial speech, the development of new business models by some of the largest commercial enterprises in the global economy is likely to strain - or at least stretch - the doctrine, which was developed to deal with more traditional direct financial fee-for-service or product purchasing transactions. Web-based titans like Facebook and Google, and rising powers like

128. Van Alstyne, supra note 127, at 1640.

129. See, e.g., Bolger v. Youngs Drug Prods. Corp., 463 U.S. 60, 67-68 (1983) (holding that an advertisement did not propose a transaction, but was commercial speech); Cent. Hudson Gas \& Elec. Corp. v. Pub. Serv. Comm'n, 447 U.S. 557, 561 (1980) (defining commercial speech as "expression related solely to the economic interests of the speaker and its audience").

130. Va. State Bd. of Pharmacy v. Va. Citizens Consumer Council, Inc., 425 U.S. 748, 762 (1976) (quoting Pittsburgh Press Co. v. Pittsburgh Comm'n on Human Relations, 413 U.S. 376, $385(1973))$. 
Pinterest, ${ }^{131}$ have abandoned direct financial transactions, instead selling consumer data to advertisers for profit. Consumers, in turn, have begun to expect that web-based services like social networking and search engines will be provided for free. However, despite the shift away from the traditional financial relationships that underlay the commercial speech test, it appears that all parties - web companies, consumers, and government actors-assume that the content that passes between the company and the consumer can be regulated.

\section{A. From Fee-for-Service to Commodifying the Consumer}

In direct contrast with the above-described iterations of the commercial speech test as articulated by courts and scholars, ${ }^{132}$ the predominant business model of social media and other Web 2.0 ventures ${ }^{133}$ is not a feefor-service model. Rather, websites such as Facebook, Pinterest, Google, Bing, and Twitter raise revenue through indirect means. Instead of charging their users a fee for access to the social media site, these companies sell their users' personal information and user-generated content (UGC) to third parties. By providing a free, attractive service that encourages users to share personal information and content, ${ }^{134}$ social networking sites are able to generate value by virtue of their ability to sell behavioral advertisements leveraged against user data, identifying for advertisers the likes and dislikes of

131. Pinterest recently raised $\$ 100$ million in additional capital at a $\$ 1.5$ billion valuation for the company. Matthew Yglesias, Pinterest Gets $\$ 1.5$ Billion Valuation, SLATE $\begin{array}{llll}\text { (May } 17, & 2012, & 12: 11 & \text { PM), }\end{array}$ http://www.slate.com/blogs/moneybox/2012/05/17/pinterest_s_1_5_billion_valuation.html. This high valuation is perhaps partially because the demographics of Pinterest userspredominantly women "between the ages of 25 and 54" with an average annual household income between $\$ 50,000$ and $\$ 70,000$ - are a group highly coveted by advertisers. Eve Mayer Orsburn, Why You Should Be Using Pinterest to Pick Up Women, Forbes (May 29, 2012, 1:03 PM), http://www.forbes.com/sites/womensmedia/2012/05/29/why-you-should-beusing-pinterest-to-pick-up-chicks/. For some industries, "Pinterest now [generates] more referral traffic than Twitter." Jordan Crook, Pinterest Now Generates More Referral Traffic than Twitter: Study, TECH CRUNCH (Mar. 8, 2012), http://techcrunch.com/2012/03/08/pinterest-now-generates-more-referral-traffic-than-twitterstudy/.

132. See supra Sections I.A-B.

133. "Web 2.0,' is fundamentally about what we use computers to do. We have moved from creating documents in Microsoft Office to living life online: searching on Google, buying and selling on eBay, watching the newest viral video on YouTube, and hanging out with our friends on mySpace and Facebook." Randal C. Picker, Competition and Privacy in Web 2.0 and the Cloud, 103 Nw. U. L. Rev. Colloquy 1, 2 (2008).

134. See Olufunmilayo B. Arewa, YouTube, UGC, and Digital Music: Competing Business and Cultural Models in the Internet Age, 104 Nw. U. L. REV. 431, 431-32 (2010). 
potential customers. ${ }^{135}$ Likewise, search engines like Google and Bing do not directly charge users for the search service, but rather profit ${ }^{136}$ from advertisers' ability to target advertisements to particular users based on current and prior search terms. ${ }^{137}$

While UGC websites have often been celebrated for enabling an explosion of creative content on the Internet-from music to political commentary ${ }^{138}$ - the less-discussed side of the UGC revolution has been the explanation of why websites have been actively facilitating UGC. As users generate and post content through UGC sites, they create an ever-increasing amount of data about themselves and their friends that the sites can "sell against" to advertisers. ${ }^{139}$ Likewise, as search engines become better able to

135. "[W]hile behavioral advertising is sometimes used as a synonym for behavioral targeting, behavioral advertising should be understood as the use of behavioral targeting for advertising purposes." Dustin D. Berger, Balancing Consumer Privacy with Behavioral Targeting, 27 SANTA ClaRA COMPUTER \& High TeCh. L.J. 3, 17 (2011) (citations omitted); see also Peter P. Swire, Peeping, 24 Berkeley TeCh. L.J. 1167, 1195 (2009). This Article refers to advertising that uses UGC or other personal user information to target advertising as behavioral advertising.

136. See 2012 Financial Tables, GOOGLE INVESTOR REL., http://investor.google.com/financial/tables.html (last visited Apr. 8, 2013). In 2011 alone, Google reported advertising revenues of over $\$ 30$ billion, though these earnings were described by some as "disappointing." Larry Kim, What Industries Contributed to Google's $\$ 37.9$ Billion in 2011 Revenues?, WORDSTREAM BLog (Jan. 23, 2012), $\mathrm{http} / / \mathrm{www}$.wordstream.com/blog/ws/2012/01/23/google-revenues.

137. It is important to note that this Article does not take a position on the utility of behavioral advertising or whether government regulation of such advertising is advisable. There are consumer benefits, as well as privacy risks, to advertisements that are purportedly personalized to an individual. See, e.g., Ben Kunz, Go Ahead, Facebook. Sell That Data, Bus. WK. (May 26, 2010), http://www.businessweek.com/technology/content/may2010/tc20100526_720314.htm (noting that "[c]onsumers have grown comfortable being tracked in databases, because, frankly, it's often useful"). But see Dana Mattioli, On Orbitz, Mac Users Steered to Pricier Hotels, $\begin{array}{llllll}\text { WALL ST. J. } & \text { (Aug. 23, 2012, } & \text { 6:07 } & \text { PM), }\end{array}$ http://online.wsj.com/article/SB10001424052702304458604577488822667325882.html?mo $\mathrm{d}=$ djemalertTECH (describing how a travel site creates a price differential for hotel rooms based on user data, including computer type). Rather, this Article seeks to focus on how new technologies and business models interact with the commercial speech doctrine's focus on direct commercial transactions.

138. Arewa, supra note 134, at 432 (citing Andrew Keen \& David Weinberger, The Good, the Bad, and the "Web 2.0," WALL ST. J. (July 18, 2007), http://online.wsj.com/article/SB1 18461274162567845.html?mod=Technology); Jeannine M. Marques, Note, Fair Use in the 21st Century: Bill Graham and Blanch v. Koons, 22 Berkeley TeCH. L.J. 331, 331 (2007) ("YouTube, MySpace, Blogspot, and countless other websites offer amateur creators (and even professional content companies like CBS) the opportunity to produce innovative content and to post it immediately and freely to a worldwide audience.").

139. See, e.g., Mark Sullivan, How Will Facebook Make Money?, PCWORLD (June 14, 2010, 10:00 PM), http://www.pcworld.com/article/198815/how_will_facebook_make_ 
track their web traffic and create searcher profiles, they are able to leverage that data for increased advertising revenues. ${ }^{140}$ The complaint in a recentlysettled class action suit against Facebook quoted Mark Zuckerberg as saying that a "trusted referral is the Holy Grail of advertising." 141 Likewise, the same complaint "quotes Facebook COO Sheryl Sandberg [as] stating that '[m]aking your customers your marketers' is 'the illusive goal we've been searching for."' 142 Although there is some controversy as to the potential profitability of the websites using consumer information to sell behavioral advertising, ${ }^{143}$ at least some sources have attempted to place a direct valuation on the personal information and UGC posted by consumers. ${ }^{144}$ A 2009 study estimated the price of behavioral advertising at " 2.68 times the price of untargeted advertising." 44 In addition to sales of behavioral advertising, Web 2.0 companies raise money merely by virtue of their large user bases. That is, the more users a web service is able to attract, the more advertisers will be willing to pay to have exposure to a larger audience. ${ }^{146}$ Thus, there

money.html (describing several ways in which Facebook leverages against user data for profit).

140. See, e.g., Ryan Singel, How Does Google Make the Big Bucks? An Infographic Answer, WIRED (July 19, 2011, 10:44 AM), http://www.wired.com/business/2011/07/googlerevenue-sources; Steven Levy, Secret of Googlenomics: Data-Fueled Recipe Brews Profitability, WIRED (May 22, 2009), http://www.wired.com/culture/culturereviews/magazine/1706/nep_googlenomics?currentPage=all.

141. Fraley v. Facebook, Inc., 830 F. Supp. 2d 785, $791-92$ (N.D. Cal. 2011) (quoting Second Amended Class Action Complaint for Damages at 143 , Fraley, 830 F. Supp. 2d 785 (No. CV 11-01726), http://www.dmlp.org/sites/citmedialaw.org/files/2011-06-062ndAmendedComplaint.pdf (challenging Facebook's "Sponsored Stories" ads under California state law protecting individuals' right to publicity). Perhaps because this suit survived a 12(b)(6) motion to dismiss, Facebook settled with Plaintiffs. Id. at 815; see Dan Levine, Facebook Settles Lawsuit Over "Sponsored Stories," ReuTers (May 22, 2012, 6:53 PM), http://www.reuters.com/article/2012/05/22/us-facebook-settlementidUSBRE84L16920120522.

142. Fraley, 830 F. Supp. 2d at 792 (second alteration in original) (quoting Second Amended Class Action Complaint for Damages at 943 ).

143. See, e.g., Jean-Louis Gassée, Mobile Advertising: The \$20B Opportunity Mirage, MONDAY NOTE (June 10, 2012, 10:39 PM), http://www.mondaynote.com/2012/06/10/ mobile-advertising-the-20b-opportunity-mirage/.

144. Alexis C. Madrigal, How Much Is Your Data Worth? Mmm. Somewhere Between Half a Cent and \$1,200, ATlantiC (Mar. 19, 2012, 3:18 PM), http://www.theatlantic.com/technology/archive/12/03/how-much-is-your-data-worth-mmmsomewhere-between-half-a-cent-and-1200/254730/ (describing various methods of evaluating the monetary value of a single user's data).

145. Catherine Tucker, The Economics Value of Online Customer Data 15 (2010), available at http://www.oecd.org/internet/ieconomy/46968839.pdf (citing HowARD BEAles, The VAlue OF BeHAVIORAL TARGETING (2010), available at http://www.networkadvertising.org/pdfs/Beales_NAI_Study.pdf); see also Ira S. Rubinstein, Regulating Privacy by Design, 26 BERKELEY TECH. L.J. 1409, 1440 (2011).

146. See, e.g., Alexis C. Madrigal, The Big Digg Lesson: A Social Network Is Worth Precisely as Much as Its Community, ATLANTIC (July 12, 2012, 6:14 PM), 
are two ways that the new online economy capitalizes on providing free services to users: (1) the more traditional route of creating a venue where a large number of eyes can be turned towards advertisements; and (2) the newer route of leveraging against user data to create targeted advertisements and consumer dossiers.

While this fast-rising business model poses interesting questions for corporate valuation and consumer privacy, this Article focuses on the implications that an indirect monetization of consumer content has on the viability of the commercial speech doctrine as currently formulated.

\section{B. User Expectations}

Perhaps part of the shift away from a fee-for-service business model and towards a data-driven model that leverages the size of a user base and the users' information has to do with shifting user expectations. The expectations of users of social networking and search engine sites may further undermine the traditional relationship between commercial actor and consumer - and therefore also undermine the current concept of commerce underlying the commercial speech doctrine.

As some scholars have noted, the rise of UGC-driven sites has upset, if not destroyed, the traditional business models of the cultural industry. ${ }^{147}$ Likewise, the rise of free services on the Internet - whether those services are search engines, social media, photo sharing, or other services - has created a user expectation that Internet services be free. ${ }^{148}$ Few people today would imagine paying for basic search engine access, use of a service like Facebook, ${ }^{149}$ or even web-based political and news content. ${ }^{150}$ Although some news sites have attempted to maintain profitability by moving to a fee-for-service model, such moves have largely been met with consumer

http://www.theatlantic.com/technology/archive/2012/07/the-big-digg-lesson-a-socialnetwork-is-worth-precisely-as-much-as-its-community/259770/ ("There is one clear lesson from Digg's sale: the technology that powered a once-massive social network is worth about $\$ 500,000$. All the rest of the value derives from the people that use it. Though scaling is tough, any developer in the world can build some profiles and let people connect up. It's an act of genius - or an act of God, by which I mean luck - to design a site constitution that makes people want to build their online lives at your URL (or in your app). Social networking companies are not technology companies as much as they are community companies.").

147. Arewa, supra note 134, at 436-37.

148. Id. at 442 ("Users increasingly expect digital content to be cheap or free.").

149. FACEBOOK, supra note 5 (stating, "It's free and always will be"); Ben Parr, No, Facebook Will Not Make You Pay to Get the New Profiles, MaSHable (Sept. 25, 2011), http://mashable.com/2011/09/25/facebook-changes-are-free/. vices).

150. Berger, supra note 135 , at 32 (noting consumers reaping benefits of free ser- 
resistance and even outrage. ${ }^{151}$ So, in some ways, consumers have chosen to "pay" for their web services by allowing their information and participation in the site to be sold against, and by being exposed to behavioral advertisements. ${ }^{152}$

At the same time, consumers remain wary of the privacy policies of the major online powers. ${ }^{153}$ Although the services are free, consumers are often troubled ${ }^{154}$ by the frequent stories of data collection, ${ }^{155}$ privacy breaches, ${ }^{156}$ and changing terms of service. ${ }^{157}$ Interestingly, these concerns do not appear to affect the customer volume or market dominance of sites like Fa-

151. See, e.g., Noah Davis, STUDY: Nearly Everyone Dislikes Paying for Entertainment Online, BUS. INSIDER (June 1, 2011, 2:53 PM), http://articles.businessinsider.com/2011 06-01/entertainment/30001918_1_entertainment-online-study-profit-motive\#ixzz1 z3bcu3vh; Public Finds Less Value in Entertainment Industry, Is Unhappy About Paying, DENVER BuS. J. (May 30, 2011, 2:12 PM), http://www.bizjournals.com/denver/news/2011/05/30/publicfinds-less-value-in.html?page=all.

152. Picker, supra note 133, at 6 ("I paid cash for Outlook but I 'pay' for Gmail by being exposed to the advertisements that it places on the far right edge of the screen."); see also Swire, supra note 135, at 1195 ("[A]n emerging argument is that behavioral advertising is essential to pay for 'free' content online-this type of advertising is the last, best hope for the newspaper industry to pay for investigative journalism and the other expenses of an independent news media.").

153. See Harris Interactive, Mobile Privacy: A User's Perspective: Summary FINDINGS 6 (2011), available at http://www.truste.com/why_TRUSTe_privacy_services/harris-mobile-survey/TRUSTeMobile-Privacy-Report-Summary.pdf (finding that privacy is the primary concern of many mobile Internet users, with " $98 \%$ of consumers express[ing] a strong desire for better controls over how their personal information is collected and used via mobile devices and apps," and " $85 \%$ want[ing] to be able to opt into or out of targeted mobile ads").

154. Andrew B. Serwin, Privacy 3.0-The Principle of Proportionality, 42 U. MicH. J.L. REFORM 869, 872 (2009) ("Despite the proliferation of privacy laws in the United States, more and more people feel they have less protection for their personal information.").

155. For example, Target recently acknowledged that its data collection practices enabled its stores to be able to identify pregnant customers and send them targeted advertising early in pregnancy, which made some customers "“queasy." Kashmir Hill, How Target Figured Out a Teen Girl Was Pregnant Before Her Father Did, ForBes (Feb. 16, 2012, 11:02 AM), http://www.forbes.com/sites/kashmirhill/2012/02/16/how-target-figured-out-ateen-girl-was-pregnant-before-her-father-did/ (quoting Andrew Pole, Target statistician).

156. In the latest of a long string of data breaches, both LinkedIn and eHarmony notified consumers in the spring of 2012 that breaches were affecting large numbers of consumer passwords. Hayley Tsukayama, LinkedIn, eHarmony Deal with Breach Aftermath, WASH. POST (June 7, 2012), http://www.washingtonpost.com/business/technology/linkedineharmony-deal-with-breach-aftermath/2012/06/07/gJQAwqs5KV_story.html.

157. See cwalters, Facebook's New Terms of Service: "We Can Do Anything We Want with Your Content. Forever.," CONSUMERIST (Feb. 15, 2009), $\mathrm{http}: / /$ consumerist.com/2009/02/facebooks-new-terms-of-service-we-can-do-anything-wewant-with-your-content-forever.html (describing a unilateral change to the Facebook Terms of Service that "grant Facebook an irrevocable, perpetual, non-exclusive, transferable, fully paid, worldwide license" to use UGC, even after a user terminates his or her account). 
cebook. ${ }^{158}$ Consumers of dominant web services, therefore, are in a position where they may feel locked into using that site $^{159}$ but have no bargaining power to ensure that their data is well looked-after. ${ }^{160}$ The sole decision point for consumers is at the initial sign-up -the companies' websites, advertisements, and terms of service should lay out data use, privacy policies, and other corporate terms. But what happens if those sources provide untrue or confusing information about how consumer data will be used?

Consumers are not in a particularly good position to correct misleading information through litigation or to demand further information that the company may be unwilling to provide. ${ }^{161}$ First, consumers are usually fairly unaware of the data use practices of the web services they use because the behavioral targeting is often invisible to the consumer ${ }^{162}$ This is compounded by the fairly fluid nature of data use policies. ${ }^{163}$ Further, the policies of websites regarding data use are often very difficult for even savvy consumers to understand. ${ }^{164}$ These features of the user-website relationship make it difficult for consumers to determine whether a site's written policies or ad-

158. "[C]onsumers' self-reported attitudes about the high importance of privacy to their online shopping decisions do not always match their actual behavior." Rubinstein, supra note 145 , at 1443 .

159. "By merely participating in the Internet economy, consumers lose control over which details about their private lives are known ...." Berger, supra note 135, at 19.

160. Id. at 46. Virtually all of these on-line terms of service are "take-it-or-leave-it"" propositions. Id. If a user is unwilling to agree to the terms of service, she will be unable to access the product. Id. Furthermore, the data input to such services via UGC is generally held permanently by the service provider. See cwalters, supra note 157. Even if a user no longer consents to the terms of service, leaves the website, or the company changes its terms, the user can only withdraw prospectively; all of the submitted data remains in the hands of the service provider. $I d$.

161. Berger, supra note 135 , at 34 . While a handful of laws grant individuals the right to see what data is held about them in the financial context, see Fair Credit Reporting Act, 15 U.S.C. $\S \S 1681-1681 \times$ (2006) (including the right to access credit reports and submit corrections) and Right to Financial Privacy Act, 12 U.S.C. $\$ 3404$ (c) (2006) (stating the customers right to access a report of all disclosures made to the government by financial institutions), this is not the norm and only reaches a very limited subset of the data held about an individual.

162. The fact that consumers are relatively unaware of such practices may be what allows them to be so effective:

Profilers certainly benefit from their obscurity when it comes to avoiding liability

for inappropriate disclosure. Even if a consumer suspected that the contents of his profile had been inappropriately used or disclosed, it would be difficult for him to discern which profiler was at fault, and, therefore, which company to contact or, perhaps, to sue. Because consumers lack this information, they may be without effective legal recourse when a profiler's use of behavioral targeting harms them.

Berger, supra note 135, at 15 (citations omitted).

163. See id. at $47-48$.

164. Fed. Trade Comm'N, FTC Staff Report: Self-Regulatory Principles for ONLINE BEHAVIORAL ADVERTISING 34-35 (2009), available at http://www.ftc.gov/os/2009/02/P085400behavadreport.pdf. 
vertisements provide them with accurate information sufficient to allow them to make an informed decision. Additionally, even if users were able to determine that they were misled by site advertisements or policies, it would likely be difficult to prove that they were damaged ${ }^{165}$ - a required element of a false advertising or unlawful business practices cause of action in many states. ${ }^{166}$ After all, it is difficult to determine the exact damages caused by a false or misleading data use policy to a user who was not paying for site access.

\section{Present Regulation by the Federal Government}

Despite the indirect financial relationship between Web 2.0 businesses and their users, it appears that both federal regulators and the companies themselves have assumed that false or misleading advertisements or terms of service can be regulated. ${ }^{167}$ However, limited regulatory authority and companies' First Amendment rights may constrain the effectiveness of such regulations.

As many commentators have noted, the Federal Trade Commission (FTC) has a rather limited scope of authority in regulating Internet companies. ${ }^{168}$ The FTC is enabled by the Federal Trade Commission Act to regu-

165. Serwin, supra note 154 , at 874,885 .

166. See, e.g., CAL. Bus. \& Prof. CODE $\S 17204$ (West 2012) (allowing suit only "by a person who has suffered injury in fact and has lost money or property as a result of the unfair competition"); N.Y. GEN. BUS. LAW $\S 349$ (McKinney 2012) (allowing suit for deceptive business practices only by the Attorney General and the individual who had been injured); Mass. Gen. Laws ch. 93A, § 9(1) (2012); TeX. Bus. \& Com. Code AnN. § 17.50(a) (West 2012) (requiring the consumer show damages to prevail on deceptive trade practices claim).

167. This Article does not consider the regulation of how such companies may use the data they have collected. The actual ways that such service providers use their users' individual data remains an area of appropriate concern for regulation and study. With our focus on terms of service and advertisements, we are not dismissing the real privacy concerns attached to appropriate data usage; they simply lie outside the scope of this Article. For an excellent consideration of data privacy and the First Amendment, see generally Richards, supra note 12.

168. See, e.g., Berger, supra note 135, at 41-42; Anne Keaty, Roger J. Johns \& Lucy L. Henke, Can Internet Service Providers and Other Secondary Parties Be Held Liable for Deceptive Online Advertising?, 58 Bus. LAw. 479, 493-94 (2002). Aside from a limited grant of authority, some commentators have recently noted that the FTC's lack of resources and bureaucratic barriers have left it unable to even investigate many sites' privacy practices. Peter Maass, How a Lone Grad Student Scooped the Government and What It Means for Your Online Privacy, MOTHER JONES (June 29, 2012, 2:00 AM), $\mathrm{http} / / \mathrm{m}$.motherjones.com/media/2012/06/stanford-grad-student-scooped-ftc-online-privacyregulation (reporting on the FTC's resource and hardware shortcomings, which include the inability of investigators to access most websites from their work computers, and using cell phone tethers and other "workaround[s]" to access sites under investigation). 
late unfair and deceptive trade practices in or affecting commerce. ${ }^{169}$ The FTC considers advertising to be deceptive if there is a material representation, omission, act, or practice that is likely to mislead reasonable consumers. ${ }^{170}$ The FTC has interpreted the materiality requirement broadly to include any information "important to a consumer's decision to buy or use the product."':71

The FTC has taken this mandate ${ }^{172}$ and applied it to regulate the behavior of websites offering free services to users that are false, misleading, or unclear about their data use policies. ${ }^{173}$ In addition to publishing selfregulatory principles for online behavioral advertising ${ }^{174}$ and issuing recommendations for a privacy framework, ${ }^{175}$ in the last two years, the FTC brought enforcement actions against two Web 2.0 titans-Facebook and Google. ${ }^{176}$ The orders obtained by the FTC in the Google and Facebook enforcement actions required, among other things, that the companies obtain consumers' affirmative consent before materially changing their data practices or policies. ${ }^{177}$ The actions also resulted in both companies agreeing to create companywide privacy programs that would be assessed by outside auditors over the next two decades. ${ }^{178}$

169. 15 U.S.C. $\S 45(a)(2)$ (2006) (listing what is also known as $\S 5$ of the Federal Trade Commission Act).

170. Keaty, Johns \& Henke, supra note 168 , at 487-88.

171. See id. at 487 (quoting Fed. Trade Comm'N, Advertising Practices: FREQUENTLY ASKED QUESTIONS: ANSWERS FOR SMALL BUSINESS 3 (2001), available at business.ftc.gov/sites/default/files/pdf/bus35-advertising-faqs-guide-small-business.pdf); Letter from James C. Miller III, Chairman, Fed. Trade Comm'n, to John D. Dingell, Chairman, Comm. on Energy \& Commerce, U.S. House of Representatives (Oct. 14, 1983), reprinted in Cliffdale Assocs., Inc., 103 F.T.C. 110 (1984), 1984 WL 565319 app. at *45; see also FED. TRADE COMM'N, supra, at 3 (describing the materiality standard and giving examples).

172. 15 U.S.C. $\S 45(a)$.

173. See, e.g., Facebook, Inc., No. 0923184 (Fed. Trade Comm'n 2011) [hereinafter Agreement Containing Consent Order, Facebook, Inc.], available at http://www.ftc.gov/os/caselist/0923184/111129facebookagree.pdf (agreement containing consent order); Google Inc., No. 1023136 (Fed. Trade Comm'n 2011) [hereinafter Agreement Containing Consent Order, Google, Inc.], available at http://www.ftc.gov/os/caselist/1023136/110330googlebuzzagreeorder.pdf (agreement containing consent order).

174. FED. TRADE COMM'N, supra note 164, at i-iv.

175. FED. TRADE COMM'N, supra note 22, at v.

176. Complaint, Facebook, Inc., supra note 25; Complaint, Google Inc., No. 102 3136 (Fed. Trade Comm'n 2011) (No. C-4336), available at http://www.ftc.gov/os/caselist/1023136/111024googlebuzzcmpt.pdf; see also Complaint, MySpace L.L.C., No. 1023058 (Fed. Trade Comm'n 2012) (No. C-), available at http://www.ftc.gov/os/caselist/1023058/120508myspacecmpt.pdf.

177. Agreement Containing Consent Order, Facebook, Inc., supra note 173, at 4-5; Agreement Containing Consent Order, Google Inc., supra note 173, at 4.

178. Agreement Containing Consent Order, Facebook, Inc., supra note 173, at 5-6; Agreement Containing Consent Order, Google Inc., supra note 173, at 4-5; see also Alma 
The FTC enforcement actions and subsequent settlements strongly imply that both the FTC and the regulated entities believe that the transactions between purveyors of free web services and their users is a commercial one. This is in contrast to purveyors of free services in another context. In at least three federal cases brought by so-called crisis pregnancy centers, the centers have made the argument that because their medical and personal counseling services are offered for free, the government can neither compel disclosures to correct false and misleading information about the services offered by these clinics nor regulate any false or misleading advertisements made by the clinics. ${ }^{179}$ At least three federal courts have found these arguments persuasive in the context of compelled disclosures. ${ }^{180}$ Under the standard suggested by these cases, companies like Facebook and Google could falsely advertise their services with impunity, and the government would be unable to compel data use or other privacy disclosures. ${ }^{181}$

To date, companies like Facebook and Google have not challenged regulation under the FTCA of false or misleading practices vis-á-vis their users. This does not mean, however, that First Amendment defenses are not being raised in consumer suits against such companies. For example, in two class actions brought against Facebook for its "Sponsored Stories" (advertisements using a friend's "like" of a commercial entity's Facebook page) under a California statute prohibiting commercial use of a person's likeness without consent, ${ }^{182}$ Facebook raised as a defense that such "likes" were newsworthy and therefore could not be restricted by the California law. ${ }^{183}$

Whitten, An Update on Buzz, Google Official Blog (Mar. 30, 2011), http://googleblog.blogspot.com/2011/03/update-on-buzz.html; Elliot Schrage, The Facebook Site Governance Vote, FACEBOOK NewSROOM (June 1, 2012), http://newsroom.fb.com/News/371/The-Facebook-Site-Governance-Vote ("[W]e have entered into a settlement agreement with the Federal Trade Commission which involves regular audits of our privacy practices ....").

179. See Greater Balt. Ctr. for Pregnancy Concerns, Inc. v. Mayor of Balt., 683 F.3d 539, 552-53 (4th Cir. 2012); Centro Tepeyac v. Montgomery Cnty., 683 F.3d 591, 594 (4th Cir. 2012), aff'g in part, rev'g in part 779 F. Supp. 2d 456, 463 (D. Md. 2011); Evergreen Ass'n v. City of N.Y., 801 F. Supp. 2d 197, 205 (S.D.N.Y. 2011); O'Brien v. Mayor of Balt., 768 F. Supp. 2d 804, 813-14 (D. Md. 2011).

180. Greater Balt. Ctr. for Pregnancy Concerns, Inc., 683 F.3d at 552-53; Centro Tepeyac, 683 F.3d at 594; Evergreen Ass'n, 801 F. Supp. 2d at 205; O'Brien, 768 F. Supp. $2 \mathrm{~d}$ at $813-14$.

181. While this Article clearly is not discussing abortion, these cases make an interesting parallel as both scenarios implicate the constitutional right of privacy on the consumer side.

182. See Second Amended Class Action Complaint for Damages, supra note 141, at 2; Original Complaint at 5-6, E.K.D. ex rel. Dawes v. Facebook, Inc., 885 F. Supp. 2d 894 (S.D. Ill. 2012) (No. 3:11-461-GPM), http://www.scribd.com/doc/56981760/E-K-D-vFacebook-Complaint; see also CAL. CIV. CoDE $\S 3344$ (a) (West 2012).

183. Facebook, Inc.'s Motion to Dismiss First Amended Class Action Complaint at 17-22, Fraley v. Facebook, Inc., 830 F. Supp. $2 d 785$ (N.D. Cal. 2011) (No. CV 11-01726); 
Also of note, Google recently commissioned scholar Eugene Volokh to draft a white paper outlining the argument that Google search results are fully protected speech. ${ }^{184}$ While neither of these examples raises issues related to the advertising or terms of service of social networking sites or search engines, they suggest that such web companies are not shy about raising First Amendment defenses where they perceive them to exist.

\section{REDEFINING THE COMMERCIAL IN AN INFORMATION ECONOMY}

\section{A. Audience-Focused Conception of Commercial Speech}

Looking back across the early cases that gave rise to First Amendment protection for commercial speech, an important difference between commercial and non-commercial speech is noticeable. Where non-commercial speech cases concern themselves primarily with the speaker, ${ }^{185}$ commercial speech is expressly concerned with the audience. ${ }^{186}$ There are different values that motivate the protection of commercial speech as compared to noncommercial speech:

\footnotetext{
Whereas communication within "public discourse" is protected both because of its participatory value to a speaker and because of its informational value to an audience, "[a] commercial advertisement is constitutionally protected not so much because it pertains to the seller's business as because it furthers the societal interest in the "free flow of commercial information." 187
}

This focus on the listener in assessing commercial speech is particularly important because, regardless of the type of speech, a speaker presumes an audience. The perspective of this audience only seems to rise to the level of constitutional concern in the realm of commercial speech. Thus some visions of commercial speech attempt to define the speech itself by looking

Memorandum of Law in Support of Motion for More Definite Statement or Dismissal, supra note 1 , at $15-18$.

184. VOLOKH \& FALK, supra note 1, at 6-20. A white paper is a report written by an expert in order to help readers understand an issue or make a decision. Such papers are mainly used in business and government decisionmaking.

185. See, e.g., Spence v. Washington, 418 U.S. 405, 410-11 (1974) (per curiam) (focusing on speaker's "intent to convey a particularized message").

186. Post, supra note 28, at 14 (noting that the Supreme Court has "focused its [commercial speech] analysis on the need to receive information, rather than on the rights of speakers").

187. Robert Post, Transparent and Efficient Markets: Compelled Commercial Speech and Coerced Commercial Association in United Foods, Zauderer, and Abood, 40 VAL. U. L. REv. 555, 559 (2006) (alteration in original) (citations omitted) (quoting Hustler Magazine, Inc. v. Falwell, 485 U.S. 46, 55 (1988)); Bethel Sch. Dist. No. 403 v. Fraser, 478 U.S. 675, 682-83 (1986); Comelius v. NAACP Legal Def. \& Educ. Fund, 473 U.S. 788, 802 (1985); First Nat'l Bank of Bos. v. Bellotti, 435 U.S. 765, 783 (1978) (quoting Va. State Bd. of Pharmacy v. Va. Citizens Consumer Council, Inc., 425 U.S. 748, 764 (1976)). 
to the expectations of the audience, rather than of the speaker, or at least on an equal footing with the speaker's expectations. ${ }^{188}$ It has not been the case that the simple exchange of money, the "commercial transaction," makes the speech at hand commercial. ${ }^{189}$ If the courts are able to conceive of interactions where money is expressly exchanged as non-commercial, it is rather the expectations of the audience that suggest whether speech should be categorized as commercial or non-commercial.

Thus, audience-or dare we say, consumer in this contextexpectations appear to undergird some of the definitional distinctions made in the commercial speech context. As in Murdock, where the audience expected the relationship to be religious as opposed to commercial-even though accompanied by "an offer to sell $(\mathrm{X})$ good or service at $(\mathrm{Y})$ price"190 - the court determined that it was in fact religious, fully-protected speech. ${ }^{191}$ We could conceive of this determination being reversed where the audience expected the relationship to be a commercial one. Focusing on consumer expectations provides a relatively clear dividing line to classify commercial and non-commercial speech and is likely sufficient for many commercial relationships.

However, in the new digital economy, we must question whether this consumer-focused paradigm will actually reach the speech with which regulators, academics, and even the Web 2.0 companies themselves are interested. ${ }^{192}$ It is conceivable that users - consumers - of some of the largest Internet companies do not imagine their relationship to be one encompassing a commercial transaction. With the trajectory of development of social media, search engines, email, and other web services being offered to the consumer at no monetary charge, it is more than likely that consumers expect use of these services not to create a classic economic relationship. ${ }^{193}$ And it is all the more likely, with the expectation of receiving these services for free, that users will be wholly unwilling to revert to a paradigm where one is charged money for each use. ${ }^{194}$

188. See Post, supra note 28, at 40; Pomeranz, supra note 105, at 423.

189. See, e.g., Murdock v. Pennsylvania, 319 U.S. 105, 111 (1943) (holding that where an audience understood the religious nature of the speech, "the mere fact that the religious literature is 'sold' by itinerant preachers rather than 'donated' does not transform evangelism into a commercial enterprise"). 761).

190. McGowan, supra note 104, at 401 (citing Va. State Bd. of Pharmacy, 425 U.S. at

191. Murdock, 319 U.S. at 111.

192. See supra notes 25-26 and accompanying text.

193. See FACEBOOK, supra note 5 (stating, "It's free and always will be").

194. See, e.g., Parr, supra note 149 (noting that rumors of Facebook beginning to charge for use circulating Internet at various intervals have caused great uproar); see also supra notes $148-52$ and accompanying text. 
Furthermore, when facing new products that operate on a different economic playing field than "an offer to sell $(\mathrm{X})$ good or service at $(\mathrm{Y})$ price," 195 it is quite likely that uniform consumer expectations may not yet even exist. For new relationships that look like classic transactions- that is, those for which people have a point of reference from the rest of their life experiences - the consumer expectations model will likely still reach the speech in which there is a valid interest in regulating. For relationships that do not have this touchstone within previous experience, however, there is cause for concern that an audience-focused approach will not reach the speech in which there is a valid regulatory interest. When entirely new economic models are rolled out, there are not yet consumer expectations tied to them, and thus an audience-focused approach may fall short of that speech we would want to be included within that realm of commercial speech.

\section{B. Commercial Speech, Consumer Expectations, and Shifting Norms}

A commercial speech test that focuses on the audience- that is, on the expectations of the speech consumer-might not capture the speech with which this Article is concerned. The advertisements of free services like Facebook, Google, Twitter, Bing, and Pinterest do not propose what a consumer might consider to be a "commercial transaction." Consumers generally do not conceptualize their relationship with free online services as being a commercial one in the "(X) good or service at $(\mathrm{Y})$ price"196 context. Rather, consumer expectations of these services are that they are free services. ${ }^{197}$ As discussed in Part II, the norm has shifted such that individuals expect as a default that their social media, search engines, and other web services will be provided free of charge. ${ }^{198}$ In the face of frequent, unsubstantiated reports of Facebook moving to a pay-for-use model, ${ }^{199}$ Facebook has worked hard to dispel these rumors, going so far as to put on the initial sign-up page that the service will always be free. ${ }^{200}$

Some savvy consumers may realize that their relationship with web services is not born of altruism by those companies, but rather is based on ad sales. Few, however, will realize that rather than a passive ad sales relationship (like that developed in the free television era), the true value of the relationship is not only as a pair of eyes to view an advertisement, but as an aggregate of individual data that can be sold to advertisers to create increas$761)$.

195. McGowan, supra note 104, at 401 (citing Va. State Bd. of Pharmacy, 425 U.S. at

196. Id.

197. See supra Section II.B.

198. See supra Section II.B.

199. See, e.g., Parr, supra note 149 (noting that rumors of Facebook beginning to charge for use circulating Internet at various intervals cause great uproar).

200. See FACEBOOK, supra note 5 (stating, "It's free and always will be"). 
ingly personalized and custom advertisements. ${ }^{201}$ Indeed, because many web companies begin offering services before monetizing-and indeed before coming up with a strategy to monetize-it is not really the consumer's fault when she doesn't conceive of the relationship as a commercial one. ${ }^{202}$

Though the suggestion that the concerns animating the commercial speech doctrine are focused on the audience rather than the speaker is not necessarily misplaced, the focus on consumer expectations to identify which speech is commercial simply does not capture the nuances of the modern web economy. What the above discussion is meant to highlight is that in the case of advertisements for free web-based services, the consumer is being commodified in a way that he or she might not realize, but that makes the transaction no less commercial. ${ }^{203}$

Accepting the audience-focused approach to commercial speech may suggest a dismissal of these concerns either (1) by claiming that the audience members using these Internet-based services understand themselves to be engaged in a commercial transaction, or (2) by asserting that the real concern is not with consumer expectations, but with ensuring the free flow of information in the commercial arena. The first of these assertions, while perhaps true for some of the more savvy consumers who are wholly aware of their data being traded on, is certainly not the universal understanding of

201. See supra Section II.A.

202. How Does Pinterest Make Money?, PinTerest HelP Center, https://help.pinterest.com/entries/22997783-How-does-Pinterest-make-money- (last visited Apr. 8, 2013) (answering the question "How does Pinterest make money?," Pinterest states, "Right now, we're focused on growing Pinterest and making it more valuable. To fund these efforts, we've taken outside investment from entrepreneurs and venture capitalists. In the past, we've tested a few different approaches to making money such as affiliate links. We might also try adding advertisements, but we haven't done this yet"); Biz Stone, Hello World, TwITTER BLOG (Apr. 13, 2010, 12:01 AM), http://blog.twitter.com/2010/04/helloworld.html; see also Brian X. Chen \& Jenna Wortham, A Game Explodes and Changes Life Overnight at a Struggling Start-Up, N.Y. TiMES, Mar. 26, 2012, at B3 (noting a game company was "not bringing in much revenue" on games, but with the advent of one popular game and the accompanying spike in number of users, it sold itself to a larger company for millions); Rob Walker, Peace, Love and Tumblr, N.Y. Times MAG., July 15, 2012, at 22, available at http://www.nytimes.com/2012/07/15/magazine/can-tumblrs-david-karpembrace-ads-without-selling-out.html (describing Tumblr founder's struggle to create profitable ad revenue through "sponsorship" and brand creation, rather than behavioral advertising).

203. In response to this commodification, some have suggested an "anti-free-software movement" that would prefer direct money-for-services transactions over the rising free services-for-data model. E.g., Alexis C. Madrigal, Why You Should Want to Pay for Software, Instagram Edition, ATLANTIC (Dec. 17, 2012, 1:10 PM), http://m.theatlantic.com/technology/archive/2012/12/why-you-should-want-to-pay-forsoftware-instagram-edition/266367/ ("Truly, the only way to get around the privacy problems inherent in advertising-supported social networks is to pay for services that we value. It's amazing what power we gain in becoming paying customers instead of the product being sold."). 
those using these so-called "free services." ${ }^{204}$ Furthermore, even if this consumer understanding was true, it still would not answer the argument of those who wish to advance a clearly outlined definition of commercial speech. ${ }^{205}$ The second of these two assertions certainly does track with the case law considering the matter. However, it can be seen as begging the question: Without a clear operative definition of commercial speech, how do we determine whether a particular area makes up part of the commercial arena in which the flow of speech can be regulated? ${ }^{206}$

\section{Toward a Modern Definition of "Commercial Transaction"}

This Article does not seek to diverge too sharply from the Bolger test for commercial speech, ${ }^{207}$ but rather to propose a change in our conception of what it means to propose a "commercial transaction" in the modern information economy. ${ }^{208}$ The old formulation of commercial speech as speech that proposes the sale of a good or service for a particular price ${ }^{209}$ needs to give way to realize the commercial value of consumer data. What we propose is that the definition of "commercial transaction" should include transactions where a company leverages consumer participation in its service as a saleable good.

There are two facets to this proposition. First, consumer participation in a "free" service is valuable in and of itself because larger audience numbers allow websites (and in the earlier formulation, network television sta-

204. Danny Goodwin, Facebook Kills Rumor, Announces 'Facebook Will Always Be Free,' SEARCH ENGINE WATCH (Sept. 26, 2011), http://searchenginewatch.com/article/2112106/Facebook-Kills-Rumor-Announces-

Facebook-Will-Always-Be-Free ('“Free to use,' anyway. The hidden cost to users is a lack of privacy ....").

205. See Earnhardt, supra note 105, at 803; McGowan, supra note 104, at 400-01.

206. Cf. Riley v. Nat'l Fed'n of the Blind of N.C., Inc., 487 U.S. 781, 795-96 (1988) (stating that the government cannot compel speech of even professional fundraisers); Zauderer v. Office of Disciplinary Counsel, 471 U.S. 626, 651-53 (1985) (holding that the state can compel content in attorney advertising, and the "interests at stake in this case are not of the same order as those discussed in Wooley, Tornillo, and Barnette").

207. Bolger v. Youngs Drug Prods. Corp., 463 U.S. 60, 66-67 (1983).

208. In many ways the new information economy is a barter economy, with something of value, in this case data, exchanged for a good or service in lieu of using money. Numerous states include barter in their definitions of sales or vending, see, e.g., ALA. CODE $\S 8-17-271$ (7) (2012) (including barter in the definition of "[s]ale" of cigarettes); ARIZ. REV. STAT. ANN. § 28-5601(29) (2012) (defining "[s]ell" to include barter); ARK. CODE ANN. § 2027-2103(6)(A) (2012) (defining "[s]ale" to include barter); CAL. FoOD \& AGRIC. CODE § 44 (West 2012) (defining "[s]ell" to include barter); MIss. CODE ANN. § 75-27-3(3) (2012) (defining "sale" and "sell" to include barter); and N.Y. TAX LAW $§ 470$ (McKinney Supp. 2012) (defining "[s]ale" to include barter), but no federal case has applied the commercial speech doctrine to an offer for bartering.

209. McGowan, supra note 104, at 401. 
tions) to sell advertisements for a premium. ${ }^{210}$ But more importantly, the personal data provided by consumers through their online participation, whether by creation of UGC on a social networking site or by the content of their searches on an Internet search engine, is of great value to these service providers.

There seems to be little disagreement that consumer data is a valuable commodity. Numerous articles have described the great and ever-increasing value of the consumer data that companies like Google, Facebook, and Microsoft are able to extract from user interactions with their web-based services. ${ }^{211}$ In some ways, commentators have noted, most web titans are running a data mining operation, offering free services as loss leaders to drive up traffic. ${ }^{212}$ Data provided by consumers is used not only by web companies to sell more targeted advertisements, which command a price premium, ${ }^{213}$ but can also be aggregated and sold to other companies. ${ }^{214}$

The leveraging of consumer data to sell advertisements or aggregate data is surely as much of a commercial enterprise as providing " $(\mathrm{X})$ good or service at (Y) price." 115 It is clear that when one of these online service providers collects user information to sell to a data aggregator or displays targeted ads for an advertiser, it is engaged in a commercial transaction. This fact underscores the value of a user base and user data. Thus, it must be the case that when users take advantage of these "free" online services they

210. Consider, for example, the premium advertisements on broadcast media during high traffic viewing such as the Super Bowl or the Academy Awards. This ad time is precisely more valuable because of the increased number of viewers, just as a large number of users bestows value on these Internet based services. It would seem apparent that even though NBC did not charge viewers for access to the channel, they could still not produce misleading advertisements about themselves.

211. See supra note 145 and accompanying text.

212. Vasant Dhar, Get Paid for Your Data on Facebook, WIRED (June 11, 2012, 2:29 PM), http://www.wired.com/business/2012/06/opinion-get-paid-for-your-fb-data/ ("As its user base grows, Facebook's data becomes its primary asset. . . Large troves of data are valuable because they make it easy to build predictive models which in turn translate into money.").

213. See, e.g., Plaintiff's Motion for Preliminary Approval of Class Action Settlement at 16-17, Fraley v. Facebook, Inc., 830 F. Supp. 2d 785 (N.D. Cal. 2011) (No. CV 11-01726) (valuing injunctive relief that limited Facebook's use of Sponsored Stories at $\$ 103$ million); Claire Hoffman, The Battle for Facebook, RolLING STONE, June 26, 2008, at 64, 70-71 (quoting Mark Zuckerberg as saying, "Nothing influences people more than a recommendation from a trusted friend. . . A trusted referral is the Holy Grail of advertising"').

214. While the Supreme Court recently considered a case involving data mining and commercial speech, Sorrell v. IMS Health Inc., 131 S. Ct. 2653 (2011), the case does not answer the questions examined here. Rather, in IMS Health, the focus was on the regulation of the transfer of data. Id. at 2659. The concern here is not with the Internet companies' use or transfer of user data, but rather the communications involved in the formative relationship between user and service provider.

215. McGowan, supra note 104, at 401 (citing Va. State Bd. of Pharmacy v. Va. Citizens Consumer Council, Inc., 425 U.S. 748, 761 (1976)). 
have exchanged something of clear value, and a commercial transaction has taken place. Advertisements designed to persuade consumers to use such services-and thus provide the company with valuable data—should also be squarely within the definition of commercial speech.

Indeed, if the exchange of consumer data (whether UGC, search data, or GPS location) for access to a free service were not considered an exchange of valued goods, many of the terms of service provided by the service providers would not be enforceable. Courts across the country have upheld so-called "clickwrap" agreements that users must accept to proceed and use the site's services ${ }^{216}$ without controversy, even in the case of sites offering free web services. ${ }^{217}$ Similar to clickwrap agreements are "browsewrap" agreements. ${ }^{218}$ Although there is some controversy over whether the distinction between clickwrap and browsewrap agreements is a useful or meaningful one ${ }^{219}$ courts have increasingly been willing to uphold even browsewrap agreements as enforceable contracts. ${ }^{220}$ Whether the terms

216. "[C]lickwrap" is generally understood to describe agreements where users are presented with a website's terms of service and must affirmatively agree with those terms, usually by clicking an "I agree" box or button. Mark A. Lemley, Terms of Use, 91 MinN. L. REV. 459, 459 (2006) (internal quotation marks omitted). Clickwrap is thus akin to a digital version of a standard form contract - a long, nonnegotiable document drafted by the party offering the service and signed by the consumer. See id. at 466 . For a helpful summary of these terms and the developing case law in this area, see generally $i d$; Ian Rambarran \& Robert Hunt, Are Browse-Wrap Agreements All They Are Wrapped Up to Be?, 9 Tul. J. TECH. \& INTELL. Prop. 173 (2007).

217. As clickwrap mimics standard form contracts of which courts are very familiar, numerous courts have readily upheld such agreements. Lemley, supra note 216 , at 466; see, e.g., Register.com, Inc. v. Verio, Inc., 356 F.3d 393, 403 (2d Cir. 2004) (stating that Internet commerce does not alter basic contract law and that a clickwrap agreement should be enforced); A.V. v. iParadigms, L.L.C., 544 F. Supp. 2d 473, 480 (E.D. Va. 2008) (holding that under Virginia law the plaintiffs assented to a clickwrap agreement after clicking on an "I Agree" icon which appeared directly below a list of terms); Recursion Software, Inc. v. Interactive Intelligence, Inc., 425 F. Supp. 2d 756, $781-83$ (N.D. Tex. 2006) (upholding a clickwrap agreement for a software download and citing cases that form a consensus on the issue); Hotmail Corp. v. Van\$ Money Pie Inc., No. C-98 JW PVT ENE, C-98-20064 JW, 1998 WL 388389, at *3-9 (N.D. Cal. Apr. 16, 1998) (assuming such an agreement was enforceable without discussing the issue).

218. "[B]rowsewrap" agreements offer users a link to the terms of service but, unlike clickwrap, do not require the user to take an affirmative step to agree to the terms. Lemley, supra note 216 , at 460 . Websites offering such browsewrap agreements apparently assume use of the site's services with knowledge (or access to knowledge) of its terms suffices as agreement to a contract.

219. See, e.g., Eric Goldman, Judge Can't Decide if Facebook's User Agreement Is a Browsewrap, but He Enforces It Anyways-Fteja v. Facebook, ERIC Goldman: TECH. \& $\begin{array}{lllllll}\text { MARKETING L. BLOG (Jan. 30, 2012, 9:25 AM), } & \end{array}$ http://blog.ericgoldman.org/archives/2012/01/court_cant_deci.htm.

220. Lemley, supra note 216 , at 460 ; see, e.g., Register.com, Inc., $356 \mathrm{~F} .3 \mathrm{~d}$ at 403 (holding that repeated use of the website with access to its terms constituted assent to those terms); PDC Labs., Inc. v. Hach Co., No. 09-1110, 2009 WL 2605270, at *3 (C.D. Ill. Aug. 
of service agreements used by companies like Facebook are considered clickwrap, browsewrap, or "“modified clickwrap," 221 courts have upheld Facebook's terms of service as an enforceable contract. ${ }^{222}$

Underlying these decisions is the understanding that, even in the case of sites offering free services, there is sufficient consideration being offered by the consumer in exchange for those services. ${ }^{223}$ This makes sense, given the real-world value of the data the consumer creates by using, interacting with, and sometimes generating content for the free site. Given the courts' implicit acceptance of the value of consumer data to websites offering free services, it seems odd to have a definition of "consumer transaction" that excludes such exchanges. The expansion of "commercial transaction" to include exchanges of free services for personal data that will be leveraged against for later ad sales or aggregation is therefore consistent with what courts enforcing web terms of service agreements already acknowledge to be an exchange of commercially valuable goods.

While changing the conception of the commercial speech doctrine to reach these transactions of the new information economy does not significantly diverge from the current definition laid out in Bolger and elsewhere, it is a critical expansion necessary to reach some of the largest commercial actors in the digital economy. A test that expands the definition of commercial speech to reach speech that is not proposing a direct fee-for-services transaction actually follows the path of Bolger quite well. Notably, it was in Bolger that the Court determined speech that did more than propose a direct

25,2009 ) (holding that a browsewrap agreement was sufficiently conspicuous to users of a website where a hyperlink to the agreement was included on multiple pages of the website in underlined, blue, contrasting text); Cairo, Inc. v. Crossmedia Servs., Inc., No. C 04-04825 JW, 2005 WL 756610, at *4-5 (N.D. Cal. Apr. 1, 2005) (holding that a visit to a website with knowledge of an arbitration agreement in its terms indicated acceptance of the arbitration); Ticketmaster Corp. v. Tickets.com, Inc., No. CV997654HLHVBKX, 2003 WL 21406289, at *2 (C.D. Cal. Mar. 7, 2003) (holding that a website's terms preventing commercial use of information were binding on a company that did not ever expressly assent); Pollstar v. Gigmania Ltd., 170 F. Supp. 2d 974, 981-82 (E.D. Cal. 2000) (refusing to find a browsewrap agreement unenforceable at the summary judgment phase).

221. Facebook's Terms of Service agreement requires affirmative assent by users, as does clickwrap, however, the terms of service are not in front of the user at the time of agreement, thus mimicking browsewrap. See supra note 24 . Because it fits neither of these models in full, one court has called such agreements "'modified clickwrap,"” acknowledging that users have in fact clicked in assent. Swift v. Zynga Game Network, Inc., 805 F. Supp. $2 d$ 904, 910-11 (N.D. Cal. 2011).

222. See, e.g., Cohen v. Facebook, Inc. (Cohen I), 798 F. Supp. 2d 1090, 1096 (N.D. Cal. 2011); Cohen v. Facebook, Inc. (Cohen II), No. C 10-5282 RS, 2011 WL 5117164, at*1 (N.D. Cal. Oct. 27, 2011); Fraley v. Facebook, Inc., 830 F. Supp. 2d 785, 805-06 (N.D. Cal. 2011); E.K.D. ex rel. Dawes v. Facebook, Inc., No. 11-461-GPM, 2012 WL 324392, at*8 (S.D. Ill. Mar. 8, 2012).

223. See Restatement (SECOND) OF Contracts $\$ 71$ (1981). 
economic transaction could still be regulated as commercial speech. ${ }^{224}$ Though not making any given factor determinative, there, the Court looked to deeper motivation behind the speech. ${ }^{225}$ Our test makes a similar move. Access to these "free" services is not provided by the benevolence of the Internet companies; rather access is granted in exchange for commercially valuable assets - a user base and user data. The motivation behind the speech of these digital companies is, in fact, classically economic. They are receiving a valuable good in exchange for their "free" services.

Furthermore, expanding the definition of commercial transactions, and thus commercial speech, to include these data-for-services leveraging relationships is also thoroughly consistent with the values underlying the commercial speech doctrine. Perhaps even more so than in the context of classic fee-for-good or fee-for-service advertising, users in the "free" digital context have a deep interest in an open flow of information, one of the key motivations behind the grant of protection for commercial speech. ${ }^{226}$ Individuals clearly understand that when they exchange money for a good or service they are engaged in an economic transaction with the speaker. Further, they are more likely, being wholly aware of the financial motivation of the speaker, to be wary when considering apparent advertising. In the new economic models discussed above, this commercial relationship is often less apparent to the users, and thus they may be less likely to turn a critical eye to the speech in question. ${ }^{227}$ Furthermore, in a transaction where the consumers may be less aware of what they are giving up, it is all the more critical that the flow of information be robust. Our test calls not just for a consistent application of the commercial speech doctrine, but for taking extremely seriously the values underlying the doctrine. The free flow of information is critical to consumer choice, ${ }^{228}$ and the commercial speech doctrine should be applied in a way that takes consumer access to information very seriously.

Some may worry that this expansion of the definition of commercial speech could lead to a slippery slope, reaching forms of speech that should be entitled to full First Amendment protection. This argument insists that there be a fee-for-goods or a fee-for-services transaction proffered in order for speech to be considered commercial. This concern is unfounded for two

224. Bolger v. Youngs Drug Prods. Corp., 463 U.S. 60, 66-67 (1983).

225. Id. at 67 (noting that courts consider the motivation underlying speech as one of three factors to determine whether the speech would be subject to commercial speech analysis).

226. Zauderer v. Office of Disciplinary Counsel, 471 U.S. 626, 651 (1985) (stating that "the extension of First Amendment protection to commercial speech is justified principally by the value to consumers of the information such speech provides").

227. See supra notes 162-67 and accompanying text.

228. Va. State Bd. of Pharmacy v. Va. Citizens Consumer Council, Inc., 425 U.S. $748,763-64(1976)$. 
reasons. Just as with all applications of the commercial speech doctrine, our test only reaches the formative relationship. ${ }^{229}$ It does not purport to " prescribe what shall be orthodox in politics, nationalism, religion, or other matters of opinion or force citizens to confess by word or act their faith therein." "'230 Where individuals are going to be leveraged by a company in order to raise capital, those individuals are clearly trading something of value, even if it just be themselves as a user ${ }^{231}$ and a commercial transaction has in fact occurred. Recognition of this fact does not prevent these companies from advocating at will in politics, religion, or any other matters of opinion. Second, this concern arises out of a confusion of the speaker and the particular speech act. The fact that it is a corporate speaker is not what answers the commercial speech question; otherwise, there would not be the separate corporate speech doctrine. Rather, in determining what constitutes commercial speech, we must look to that particular speech act itself and whether it is one concerned with the formation of a commercial relationship, including such a relationship where the exchange is not simply one of a fee-for-goods or fee-for-services, but where the individual gives up his or hersel $f^{332}$ in order to access "free" goods or services.

\section{CONCLUSION}

This call for an expansion of the definition of commercial speech comes at a time when protections for corporate speech are on the rise. ${ }^{233}$ Without wading into the particular arguments over corporate speech versus commercial speech, ${ }^{234}$ this Article stresses the importance of a continued, consistent application of the commercial speech doctrine in the face of an

229. Our explicit focus on the formative relationship is perhaps also the first step in thinking about the question of whether our expansion of the definition of commercial speech creates a danger of government prohibition of false representations made by users of these "free" services. Notably, in the standard fee-for-service context, it is only the offer of the commercial transaction - the speech of the seller-that is subject to commercial speech regulation. This fact should not change simply because the definition of commercial transaction has been expanded to meet the realities of the digital economy.

230. Zauderer, 471 U.S. at 651 (quoting W. Va. State Bd. of Educ. v. Barnette, 319 U.S. $624,642(1943))$.

231. Consider the utility to a company to be able to claim to advertisers or funders: "We have XX users."

232. By this we mean either giving up their personal data or allowing themselves to be deployed in the manner suggested in supra note 231, where the very fact of one's use of the so-called "free" services is of value to be leveraged against.

233. See, e.g., Sorrell v. IMS Health Inc., 131 S. Ct. 2653, 2672 (2011); Citizens United v. Fed. Election Comm'n, 558 U.S. 310, 372 (2010); VoLOKH \& FALK, supra note 1, at 6 .

234. Piety, supra note 105 , at 2584 (noting that the "trend is to offer broader protection to commercial speech and corporate speakers than has been extended in the past"); see also id. at 2592-604 (comparing the corporate and commercial speech doctrines). 
ascendant economic model. Every legal doctrine arises in a particularized historical period, but as the Court has consistently noted, cognizance of this historical reality does not cabin the application of the doctrine solely to the problems of that time period. ${ }^{235}$ Keeping this in mind, it seems obvious that the definition of commercial speech should be expanded to reach the transactional relationship that has become so common across the past decades that huge portions of our population undertake it multiple times a day. ${ }^{236}$.

It is of perhaps greater importance in a time of increased protection of commercial speakers to have a commercial speech test that maps more completely to the economic transactions of the day. Where corporate actors otherwise have a full panoply of speech rights, ${ }^{237}$ it is critical that consumers be able to access the full scope of necessary information when interacting with these increasingly powerful actors. Simply because speech rights now enure in much of the speech of corporate actors, it does not follow that all speech should have the same height of First Amendment protection. Such a conclusion conflates the speaker with the particular speech act and loses sight of the values underlying the commercial speech doctrine.

Once again, it is important to recognize the benefits afforded by Facebook, Google, and other free web services. The ability to connect socially across states, countries, and continents; share photographs and ideas with a worldwide audience; and have questions about politics, science, the arts, sports, music, and a panoply of other areas answered instantaneously are of

235. District of Columbia v. Heller, 554 U.S. 570, 582 (2008) ("Some have made the argument, bordering on the frivolous, that only those arms in existence in the 18th century are protected by the Second Amendment. We do not interpret constitutional rights that way."); Reno v. ACLU, 521 U.S. 844, 849 (1997) (holding that the First Amendment provides protections for modern forms of communication); Kyllo v. United States, 533 U.S. 27, 35-36 (2001) (holding that the Fourth Amendment applies to modern methods forms of surveillance). That these cases deal with the expansion of protection of rights is of no notice in arguing for the expansion of the commercial speech doctrine. Notably, the commercial speech doctrine did not rise out of an effort to limit First Amendment protection, but it allowed the extension of some protection to a type of speech that previously had no constitutional status.

236. Survey-The Frequency of Checking One's Facebook Account, STATISTA, http://www.statista.com/statistics/155166/frequency-of-checking-of-facebook-accounts-byus-users/ (last visited Apr. 8, 2013) (noting that over half of Facebook users in the United States check their account at least once a day; over $60 \%$ of users under twenty-five years old check their account at least once a day); Andrew Eisner, How Addicting Is Social Media?, RETREVO BloG (Oct. 9, 2009, 1:26 PM), http://www.retrevo.com/content/blog/2009/10/howaddicting-social-media $\% 3 \mathrm{~F}$ (presenting survey findings that $83 \%$ of Facebook users under the age of thirty-five check Facebook once a day, with $27 \%$ checking over ten times per day); Kristen Purcell, Pew Internet, Search and Email Still Top the List of Most POPUlAR ONLINE ACTIVITIES (2011), available at http://pewinternet.org/ /media// Files/Reports/2011/PIP_Search-and-Email.pdf (finding over half of American adults use email and search engines daily).

237. See generally Citizens United, 558 U.S. 310. 
great value. Such services have even proven useful, indeed critical, for real world political and social change. ${ }^{238}$ That these services are offered for no monetary charge has the potential to act as a great equalizer in the ability of people of different socioeconomic groups to access information, art, and friendship on a global basis. This Article does not argue that such services can or should be put out of business, or even delve into the question of whether they should limit their use of consumer data. But consumers deserve to know what they are getting into when they agree to trade their personal data for access to search engines, social networks, and other web applications yet to be created. At the very least, the commercial speech doctrine should stretch to allow consumers to decide whether, and under what terms, they are willing to become commodities.

238. Racha Mourtada \& Fadi Salem, Civil Movements: The Impact of Twitter and Facebook, ARAB SOC. MEDIA REP., May 2011, at 1, 1, available at http://www.dsg.ae/en/ASMR2/Images/report.pdf. 